Anuario da Facultade de Dereito da Universidade da Coruña

Vol. 23 (2019), pp. 92-123

ISSNe: 2530-6324 || ISSN: 1138-039X

DOI: https://doi.org/10.17979/afdudc.2019.23.0.6013

\title{
DE LA USURA RECOPILADA A LA USURA CODIFICADA: UNA CUESTIÓN JUZGADA POR EL SIGLO
}

\section{FROM COLLECTED USURY TO CODIFIED USURY: A MATTER JUDGED BY THE CENTURY}

\author{
JULIÁN GÓMEZ DE MAYA \\ Doctor en Derecho \\ Profesor Asociado de Historia del Derecho (Universidad de Murcia)
}

\begin{abstract}
Resumen: La secularización jurídica comienza a plasmarse en las leyes a lo largo del siglo XIX. Se trata de un fenómeno que incluye la despenalización de ciertos delitos históricamente traspasados por la idea de pecado, como el delito de usura. Sin embargo, ya desde la centuria anterior se había manifestado en la doctrina patria y el usus fori un sentido expansivo de los casos en que el prestamista podía ver justificado su beneficio o interés. Así, sin continuismo ni ruptura tajante, se advierte una evolución que acabará accediendo a la codificación patria con zigzagueante tratamiento: la supresión de la usura en 1822, salvo en su forma más mezquina; la inclusión, a partir de 1848, de las irregularidades formales en la administración de las casas de préstamo; el añadido desde 1928 de otras figuras delictivas restauradoras en parte de la estricta usura; por último, su descarte de nuevo por el Código vigente.
\end{abstract}

Palabras clave: laicización jurídica, codificación penal, clasificación delictiva, delitos religiosos, usura.

\begin{abstract}
Legal secularization begins to take shape in the laws throughout the nineteenth century. It is a phenomenon that includes the decriminalization of certain crimes historically traded by the idea of sin, such as the crime of usury. However, since the previous century it had manifested in the national doctrine and the usus fori of an expansive sense of the cases in which the lender could see justified its benefit or interest. Thus, without continuity or sharp rupture, one can see an evolution that will end up accessing the process of codification with sinuous treatment: the repeal of the crime of usury in 1822, except in its pettiest form; the inclusion, beginning in 1848, of formal irregularities in the administration of loan houses; the addition since 1928 of other restorative criminal figures in part of the strict usury; finally, it has been discarded again by the current Code.
\end{abstract}

Keywords: legal secularization, penal codification, criminal classification, religious offenses, usury. 
Sumario: I. CONSIDERACIÓN DE LA USURA EN EL TRÁNSITO DE LOS SIGLOS XVIII A XIX. II. EL CÓDIGO PENAL DE 1822. III. DEL CÓDIGO DE 1848 AL DE 1870. IV. NUEVA REPRESIÓN DE LA USURA EN EL SIGLO XX. V. RECAPITULACIÓN. VI. BIBLIOGRAFÍA.

$* \quad *$

El 15 de julio de 1805, al promulgar Carlos IV la Novísima Recopilación de las Leyes de España, renueva su vigor una serie de disposiciones reguladoras de la usura en lo civil y en lo criminal, de variopinto origen - alguna del siglo XIV-, mas siempre con norte restrictivo o represor ${ }^{1}$; y no se olvide la prelación de fuentes fijada también por el trecentista Ordenamiento de Alcalá hasta recalar, a través de las Leyes de Toro y la Nueva Recopilación, en esta Novísima ${ }^{2}$, con lo que pudiera implicar de hipotética subsistencia de otras determinaciones sobre el precio por el uso del dinero prestado procedentes de las Partidas ${ }^{3}$, del Fuero Real ${ }^{4}$, de los fueros y costumbres locales y aun del Fuero Juzgo ${ }^{5}$..., más los Derechos peninsulares exocastellanos supervivientes a los Decretos de Nueva Planta ${ }^{6}$ y un acervo canonístico ${ }^{7}$ de genealogía tanto o más medieval que no descuidaba este delito de fuero mixto, perseguible así por los tribunales regios como por los eclesiales; todo ello matizado en la práctica, esto sí, por un estructural arbitrium iudicis. Muy esquemáticamente, una panorámica de las diversas actitudes o políticas del poder frente a las conductas susceptibles de caer dentro de la noción de usura pasaría por triple alternativa: transigencia con una hipotéticamente equilibrada libertad entre las partes contratantes o al menos con un cierto desequilibrio desprovisto de reconvención penal, señalamiento de un maximum o tasa legal al lucro pactable y prohibición de todo interés en consonancia con las más moralistas lecturas del anatema bíblico $^{8}$, tres criterios con sus correspondientes concreciones históricas ${ }^{9}$ : en el primer supuesto, no hay cabida para el injusto usurario, sino solo legítimo y nudo interés, el intermedio discrimina entre uno y otro concepto, contemporizador, y en el último cualquier rendimiento se reputará en todo caso usura al hacerse sinónimos ambos vocablos: en su caso, la reprobación podrá restringirse a lo civil o desplegarse además criminalmente. Con reducción del visor al entorno que importa focalizar, en concreto y según avisaba el penalista Landrove en su tesis de doctorado, a instigación de consideraciones no estrictamente jurídicas, sino de carácter económico, político, social, religioso e incluso racial, «el proceso de criminalización de la usura sufre en

\footnotetext{
${ }^{1}$ Novísima recopilacion de las Leyes de España [NRLE], II.4.4; X.1.20-22 y 24; X.11.12; XI.28.3; XII.22, específico «De las usuras y logros»; XII.32.9.

${ }^{2}$ El Ordenamiento de las Leyes que D. Alfonso XI hizo en las Cortes de Alcalá de Henares el año de mil trescientos y quarenta y ocho [OA], XXVIII.1; Cuaderno de las leyes y nuevas decisiones hechas y ordenadas en la ciudad de Toro, I; Nueva recopilacion de las Leyes destos Reynos, III.1.3; NRLE, III.2.3.

${ }^{3}$ Las siete Partidas del Rey Don Alfonso el Sabio [P], I.6.58; I.13.9; V.11.31 y 40; VI.15.2.

${ }^{4}$ Fuero Real del Rey Don Alonso el Sabio, IV.2.5, 6.

${ }^{5}$ Fuero Juzgo ó Libro de los Jueces, V.5, 4, 8 y 9. Sobre peculiarismo local, TOMÁS Y VALIENTE, F., El Derecho penal de la Monarquía absoluta (siglos XVI, XVII y XVIII) (Madrid, 1969), p. 25.

${ }^{6}$ Sintéticamente, COVIÁN, V., «Usura», en Enciclopedia jurídica española (Barcelona, 1910), t. XXX, pp. 660-661; o VIZCARRO, C. F., El préstamo usurario (Barcelona, 1963), pp. 26-27.

7 Véase JIMÉNEZ MUÑOZ, F. J., «El tratamiento de los intereses en el Derecho canónico y en el Derecho islámico», Revista de Derecho UNED, n 3, 2008, pp. 73-77, 82-83.

${ }^{8}$ V. gr., Ex. 22, 24; Lev. 25, 35-37; Dt. 23, 20-21; Neh. 5, 1-13; Sal. 15, 5; Prov. 28, 8; Ez. 18, 8; etc.

${ }^{9}$ V. gr., ESCRICHE, J., Diccionario razonado de legislacion y jurisprudencia (Madrid, 1838/1845), t. II, pp. 505-507, 510-513; o COVIÁN, «Usura», pp. 638-640.
} 
nuestra patria alternativas no superadas quizá por infracción alguna, épocas de total anatemización, de tolerancia, de libertad absoluta... hasta llegar a cristalizar en el actual régimen de punición» ${ }^{10}$, con la nota de que, bajo el presumible imperio del principio básico de intervención mínima y ultima ratio, «es ciertamente dudoso que su oscilación pendular se justifique siempre por un correlativo vaivén de la incidencia de su manifestación social» ${ }^{11}$. Mas antes de inquirir a través de qué iter legislativo se verifica semejante evolución y bajo qué influjos, convendrá atender al statu quo de que se parte ya avanzado el siglo XVIII hacia el fenómeno codificador, con una estela normativa en la que - salvo la elección proscriptora en las Partidas y el Ordenamiento de Alcalá $^{12}$ domina el sistema de tasa.

\section{CONSIDERACIÓN DE LA USURA EN EL TRÁNSITO DE LOS SIGLOS XVIII A XIX}

Conforme advierte el profesor Sainz Guerra, «[...] aunque el delito siguiera tipificado por las leyes del Antiguo Régimen hasta el CP. de 1848, éstas no se aplicaban desde hacía tiempo a una realidad económica que ya había arrasado los límites morales que el derecho común había establecido» ${ }^{13}$; y es que, abriendo algo más el abanico de condicionantes, el mismo citado Landrove detecta cómo «con la llegada del siglo XVIII se produce en la generalidad de países, y España no constituye una excepción, una revisión minuciosa de todas las orientaciones precedentes» ante la política criminológica, a remolque de una transformación poliédrica que se extiende a regímenes políticos, estructuras sociales, doctrinas económicas $\mathrm{y}$, en fin, valores morales paulatinamente embebidos por la laicización del siglo ${ }^{14}$. Se impone comprobar ahora, por tanto, en qué proporción sea ello así, desde cuándo, a impulso de qué ponderaciones y cómo se deja notar la supuesta inaplicación o con qué viveza se manifiesta ese abandono de la perspectiva tenida por válida a lo largo de la ya declinante Edad Moderna; y ello con atención, por una parte, a la latitud material reconocida al concepto de usura y, por otra, a la pervivencia o declive de la respuesta punitiva aprestada por recopilaciones legales y cánones contra el usurero: pérdida del capital doblado por la primera vez, confiscación de la mitad de sus bienes por la segunda y de todo el patrimonio por la tercera, más la infamia e inhabilitación perpetua para empleo honorífico, privación de la facultad de testar y exclusión de enterramiento eclesiástico ${ }^{15}$.

Entre las prácticos forenses dieciochescos, Berní y Catalá continúa hablando mediada la centuria de la maldad de este delito, pero además sin excluir siquiera de su andanada cierto beneficio retributivo que se pudiera tener por lícito en esta definición de «otro de los pecados que con mas frequencia se comete, [...] peste de la Republica, y origen de muchos males»: por lo tanto, «usura comete, el que presta alguna cosa, y cobra algun lucro temporal, amás de la suerte principal», sin salvedades ni atenuantes ni

\footnotetext{
${ }^{10}$ LANDROVE DÍAZ, G., El delito de usura (Barcelona, 1968), p. 257.

${ }^{11}$ GÓMEZ RIVERO, M. C., «La usura: cuarenta y tantos años después», en VV. AA. (dirs. F. Muñoz Conde et al., ed.-coord. M. A. Núñez Paz), Un Derecho penal comprometido: Libro Homenaje al Prof. Dr. Gerardo Landrove Díaz (Valencia, 2011), pp. 500-501, 505.

${ }^{12}$ P, V.11.40; $O A$, XXIII.1-2.

${ }^{13}$ SAINZ GUERRA, J., La evolución del Derecho Penal en España (Jaén, 2004), p. 841.

${ }^{14}$ LANDROVE DÍAZ, El delito..., p. 25.

${ }^{15}$ Cfr. nota 1. Complétese en MASFERRER DOMINGO, A., La pena de infamia en el Derecho histórico español: contribución al estudio de la tradición penal europea en el marco del ius commune (Madrid, 2001), pp. 288-289.
} 
mayores sutilezas ${ }^{16}$; ahora bien, omite ya, de su cuenta, todo escarmiento confiscatorio al usurero. Con menor rigidez, Elizondo en 1764, tras admitir la usura restauratoria o en compensación de lucro cesante y daño emergente, así como la punitiva de la morosidad del deudor, tiene para sí que solo «la usura lucrativa es impía contra Dios, peligrosa contra uno mismo, é iniqua contra el próximo» ${ }^{17}$. También José Febrero arma en 1769 su diatriba, de un lado, sobre la índole pecaminosa de tales comportamientos ${ }^{18}$, de otro y por más que «[...] es proceder casi en infinito el epilogar, y concretar todos los casos que pueden ocurrir», sobre el despliegue de un porfiado casuismo a caza de la usura simulada $^{19}$ : en resumen, la compensatoria (a cuyos factores agrega la asecuración ante el peligro de perder el capital) y la punitoria o monitoria resultan lícitas, en tanto «la usura lucratoria está prohibida por todos derechos $\rangle^{20}$, consignando todavía la tasa comercial del cinco por ciento establecida mediante pragmática de 1652 y a la espera de la subida hasta el seis de porcentaje, a estilo de comercio, en $1784^{21}$. Puede ya Álvarez Posadilla reflejar en su Práctica de 1794 esa revisada tasa mercantil del seis por ciento, pero incluso esta la interpreta al cabo con notable elasticidad: «si el que dá el dinero no acostumbra á hacer uso de él para comerciar, [...] aunque en el fuero de la conciencia sería usurero qualesquiera que sin haber verdadero lucro cesante ó daño emergente diera intereses, en el externo sino pasaba del 6 por 100 , con dificultad se le podria [...] condenar por usurero» ${ }^{22}$; pero hay más: incluso «[...] se excusaría de pena» por usurero el mutuante que exigiera «lo mismo otro qualesquiera interes que justificase que verdadera é indubitablemente habia perdido igual á lo que llevase, aunque fuese mas del 6 por $100 »$, siempre que lo probara con evidencias y no por conjeturas ${ }^{23}$. Vizcaíno, en cambio - año 1797- no expande en ninguno de ambos sentidos el tenor de la real cédula ni enmienda los correctivos dispuestos ${ }^{24}$. Sí en la línea de progresiva justificación de ciertas formas cohonestables de interés, el Teatro de la legislacion, de Pérez y López, en 1798, si bien allega cuanta normativa canónica y secular entiende en su vigor, va a mostrarse alejado de todo extremo cuando amoneste que «no debemos [...] entender por usuras las ganancias justas y moderadas, el resarcimiento de los gastos y pérdidas, el interés considerable que resulta del mucho daño ó peligro á que se deponen los intereses $»^{25}$. Apenas mudado el siglo, Dou Bassols se pliega al encuadre tradicional antes de verter los castigos de la Recopilación, denunciando dúplice agravio - a la economía pública además del inferido a los particulares en sus bienes- con «[...] las razones, que me parecen mas proporcionadas y poderosas para probar lo que muchos hallan dificil de entender, que la usura sea prohibida por derecho natural y

\footnotetext{
${ }^{16}$ BERNÍ, J., Practica criminal (Valencia, 1749), pp. 11, 13.

17 ELIZONDO, F. A., Práctica universal forense de los tribunales de España, y de las Indias (Madrid, 1788), t. I, p. 43.

${ }^{18}$ FEBRERO, J., Librería de escribanos, é instruccion jurídica teorico práctica de principiantes (Madrid, 1769/1781), Parte $1^{\text {a }}$, t. II, pp. 20, 28.

${ }^{19}$ FEBRERO, Librería..., Parte $1^{\text {a }}$, t. II, pp. 18-28.

${ }^{20}$ FEBRERO, Librería..., Parte $1^{\text {a }}$, t. II, p. 19; t. III, pp. 10-11.

${ }^{21}$ FEBRERO, Librería..., Parte $1^{\text {a }}$, t. II, p. 2. Consúltese dicha normativa ya recopilada en NRLE X.1.22 y X.11.12.

22 ÁlVAREZ POSADILLA, J., Práctica criminal por principios, ó modo y forma de instruir los procesos criminales de las causas de oficio de justicia (Valladolid, 1802), t. III, pp. 460-461.

${ }^{23}$ ÁlVAREZ POSADILLA, Práctica..., t. III, p. 459.

${ }^{24}$ VIZCAÍNO PÉREZ, V., Codigo y práctica criminal, arreglado a las leyes de España (Madrid, 1797), t. II, p. 400.

${ }^{25}$ PÉREZ Y LÓPEZ, A. X., Teatro de la legislacion universal de España é Indias (Madrid, 1791/1798), t. XXVIII, p. 352.
} 
digna de mirarse con ódio y aborrecimiento [...]» ${ }^{26}$. A medio camino hacia actitudes más flexibles, Juan Sala en su Ilustración del Derecho real de España, de 1803, prosigue distinguiendo las prohibidas usuras lucratorias de las compensatorias, toleradas por razon de daño emergente ó lucro cesante, con invocación del uso de comercio, que ya nos consta cómo en realidad es, condiciona o acata la prescripción legal de 1784: de ahí arriba, todo exceso en las ganancias se reputará injusto y acreedor a las penas positivas, lo que le lleva a criticar la publicación y uso en la Universidad de Valencia de los Elementa iuris secundum ordinem pandectarum adornata de Heinecio (1681-1741) sin darlos censurados en su erróneo posicionamiento acorde con la licitud de toda usura ${ }^{27}$, como sí se previniera entonces con algún otro tratado de heterodoxa orientación legitimadora $^{28}$. La Práctica de Gutiérrez se atiene en 1806 a la erudición cultural y jurídica ${ }^{29}$, siendo tal vez el último escoliasta en mostrarse complaciente de pleno con el tradicional tratamiento, como hicieran antes la Librería de Jueces (1768) de Manuel Silvestre Martínez ${ }^{30}$, las Instituciones del Derecho civil de Castilla (1771) de Asso y Manuel ${ }^{31}$ o el Diccionario histórico y forense (1779) de Cornejo ${ }^{32}$ o el Manual alfabético de delitos y penas según las leyes y pragmáticas de España (1791) de Echebarría $^{33}$ : la lectura y detenimiento también en uno y otros quiere cartografiar un paisaje sometido a dispares tensiones, carente de unanimidad. Acabemos el repaso: con talante práctico de todo en todo, el abogado Senén Vilanova aborda en 1807 la Materia criminal forense y, por lo concerniente a la usura, se aplica a segregar la conducta conforme y tolerable de la ímproba, mala é insufrible, pero de esta excluye no solo el lucro cesante, el daño emergente y la aseguración del peligro a que el principal se expone, sino otras excusas como dificultad, incomodidad, y gastos en su restauracion y recobro o la escasa cantidad, además de reservar la inquisición de oficio, con prudente y jurídico arbitrio, a los solos casos de usura real y manifiesta perpetrada por usurero notorio y públicamente difamado, al cual, a la postre, no le señala mayores consecuencias penales $-\mathrm{y}$ a su entender amedrentan- que la pérdida del haber emprestado y otro tanto en concepto de multa, sin mención de confiscaciones en grado ninguno ${ }^{34}$.

Aquí y hasta aquí, nadie ha hablado de abandonar al solo juego de las partes la concertación de las contraprestaciones contractuales, nadie siquiera de suspender el embate penal contra la usura, acotando en el campo del ordenamiento jurídico-privado el control de los intereses convenidos: únicamente se ha llegado en España a ensanchar la justificación y con ello la magnitud de los intereses que cabe llevar en conciencia y

\footnotetext{
${ }^{26}$ DOU Y DE BASSÓLS, R. L., Instituciones del Derecho público general de España, con noticia del particular de Cataluña y de las principales reglas de gobierno en qualquier estado (Madrid, 1800/1802), t. VII, p. 408.

27 SALA, J., Ilustracion del Derecho real de España (Madrid, 1832), t. II, pp. 77-78. Véase el Plan de estudios aprobado por S. M. y mandado observar en la Universidad de Valencia (Madrid, 1787), p. 13.

${ }^{28} \mathrm{Cfr}$. nota 35 .

${ }^{29}$ GUTIÉRREZ, J. M., Practica criminal de España (Madrid, 1804/1806), t. III, pp. 102-105.

${ }^{30}$ MARTÍNEZ, M. S., Librería de jueces, utilisima y universal (Madrid, 1791), t. VIII, pp. 153-154.

31 ASSO Y DEL RÍO, I. J., y MANUEL Y RODRÍGUEZ, M. de, Instituciones del Derecho civil de Castilla (Madrid, 1805), p. 240.

${ }^{32}$ CORNEJO, A., Diccionario histórico, y forense del Derecho real de España (Madrid, 1779), pp. 600602.

${ }^{33}$ ECHEBARRÍA Y OJEDA, P. A., Los delitos y las penas en el Diccionario de Echebarría de 1791, ed. B. Mapelli Caffarena y A. García Benítez (Sevilla, 2006), pp. 100-101.

${ }^{34}$ VILANOVA Y MAÑES, S., Materia criminal forense, ó tratado universal teórico y práctico, de los delitos y delincuentes en género y especie, para la segura y conforme expedicion de las causas de esta naturaleza (París, 1827), t. III, pp. 173-177.
} 
sin repulsa penal ni civil, mas tampoco de raíz ética. Y - huelga decirlo- en la calicata emprendida se han seleccionado obras de juristas más o menos expectantes ante las soluciones practicadas en el foro, también más o menos elásticos en sus veredictos: no cesa de blandirse, en paralelo, la más rigurosa percepción teológica de la ilicitud usuraria, mas, ya expuesta al rifirrafe especulativo, su suerte parece echada ante los requerimientos de la política económica ${ }^{35}$. En todo caso, se hace palpable la cauta tendencia aperturista y liberalizadora del derecho contractual. Mucho llevaba adelantado en semejante travesía la mayor parte del resto de Europa, donde la expansiva proyección del protestantismo tenía consagrada una ética del trabajo y el ahorro, del esfuerzo y el talento, del triunfo o enriquecimiento como cauce de ascenso social en la que el préstamo a interés, sin tantas cortapisas moralistas, había obtenido más expedito encaje. $\mathrm{Y}$, sin embargo, tampoco la acción legislativa al norte de los Pirineos aparece exenta de vacilaciones: apenas salvada la coyuntura del cambio de centuria y en la esfera jurídicoprivada —nos entera Covián-, en 1804 «el Código de Napoleón, reproducido después por otros muchos, abandona el criterio de tasa en cuanto al interés convencional, pero el sistema de libertad dura muy poco, pues se retrocede al anterior, y una ley especial civil y penal, la de 3 de septiembre de 1807, determina que dicho interés no podrá exceder [...]» de sendos techos porcentuales para lo civil y, solo desregularizado a la altura de 1886, para lo mercantil ${ }^{36}$; si bien, en lo penal, el Código de 1810 toma resueltamente el partido de la desincriminación. Cabe preguntarse entonces por el simultáneo avance de la reflexión intelectual europea a lo largo de esa misma segunda mitad del XVIII vista sobre los escritos doctrinales patrios, al objeto de entender de qué manera el legislador ultrapirenaico venía a dictar en primera instancia solución penal tan distinta de la remachada en el intermedio año de 1805 por - feliz hallazgo descriptivo de Tomás y Valiente- la tardía y Novísima Recopilación española ${ }^{37}$, con su normación secular.

En 1748 el Barón de Montesquieu, al tratar Del espíritu de las leyes, tiene para sí que «la pobreza y la inseguridad de las fortunas en los Estados despóticos naturalizan en ellos la usura, ya que cada cual aumenta el precio de su dinero según el riesgo que corre al prestarlo» ${ }^{38}$, luego parece que, por contraposición, no habría de ser propia de una república democrática. Tras tender una mirada sobre la experiencia histórica, concluye que con la medida proscriptora de los préstamos a interés ocurre «[...] lo mismo que con todas aquellas en las que el legislador lleva las cosas al extremo: se encontró el modo de eludirla», toda vez que «los negocios tienen que seguir su marcha; un Estado está perdido si se ve invadido por la inacción» ${ }^{39}$, que en realidad, subterráneamente y por una fuerza incontenible, no sería tal, «porque es preciso que los negocios de la sociedad sigan su marcha, introduciéndose entonces la usura", siempre aniquilada y siempre renaciente, si bien en grado terrible cuando llegan a abolirse los medios honrados de prestar y de tomar a préstamo. Por consiguiente, antes que la prohibición, más sensato parece dejar las contraprestaciones reducidas al límite justo

\footnotetext{
${ }^{35}$ Véase ÁLVAREZ CORA, E., «Usura y censura del Santo Oficio en el siglo XVIII», en VV. AA. (ed. E. Gacto Fernández), Inquisición y censura: el acoso a la inteligencia en España (Madrid, 2006), pp. 283-297; para otras arremetidas censorias, ÁLVAREZ CORA, E., «El Derecho penal ilustrado bajo la censura del Santo Oficio», ibidem, pp. 187-200.

${ }^{36}$ COVIAN, «Usura», p. 640. Cfr. nota 90; y véase RAUTER, J. F., Théorique et pratique du Droit criminel français, ou cours de législation criminelle (Paris, 1836), t. I, pp. 586-588.

${ }^{37}$ TOMÁS Y VALIENTE, F., Manual de Historia del Derecho español (Madrid, 1981), p. 397.

${ }^{38}$ MONTESQUIEU, Barón de, Del espíritu de las leyes, trad. M. Blázquez y P. de Vega (Madrid, 2003), p. 109.

${ }^{39}$ MONTESQUIEU, Del espiritu..., pp. 491, 494.
} 
por la tasa legal ${ }^{40}$; más allá, únicamente admite el pensador aquitano el castigo penal al prestamista usurero cuando obre en abuso de niños de familia y menores ${ }^{41}$ : la excepción conocerá amplio recorrido en la generalidad de procesos codificadores.

Incidentalmente, pero imbuido del espíritu novatorio, Voltaire, en su Dictionnaire philosophique, de 1764, aboga por despojar el préstamo con intereses de toda supeditación moralista y transferirlo por completo a la ley civil ${ }^{42}$. Equidistante a la estela de Montesquieu, Joachim Faiguet de Villeneuve, economista bretón, redacta la voz «Usure» para el postrero tomo de texto de L'Encyclopédie de Diderot y D'Alembert, editado en 1765, y sin vencerse hacia el extremo se manifiesta tan desafecto a la rígida proscripción paralizante de la economía como a favor del interés moderado, incluso si tocase en lucrativo sin conculcación del sistema de tasa legal, que califica como le vrai bien, le bien général de la sociétét ${ }^{43}$. nada explana acerca de la actuaciones penales contra el transgresor, ya por exorbitancia, ya por los infames artificios de estos enemigos de la sociedad, que están ocupados solamente en tender sus redes bajo los pies de los muchachos jóvenes, con miras a sorprenderlos y despojarlos ${ }^{44}$. Más radical en la doctrina, el fisiócrata Jacques Turgot en su Memoria sobre los préstamos de dinero, de 1769 y traducida a nuestra lengua en 1828, preconiza la «necesidad de abandonar la fijación del interés en el comercio á las convenciones de los negociantes y al curso de las diferentes causas que le hacen variar» ${ }^{45}$, pero con una sola salvedad ya reseñada en el Barón y que hará fortuna a su dictado: «entre los géneros de usura a que «[...] se limita hoy la mancha que lleva consigo el nombre de usurero», resulta que el único «[...] que hace algun mal real á la sociedad» viene referido «[...] á aquellos hombres infames que hacen oficio de suministrar, con grandes intereses, á los hijos de familia de una conducta desarreglada los medios de satisfacer su libertinage y ocurrir á sus locos y supérfluos gastos» ${ }^{46}$. Scipion Bexon, invocado en las Cortes del Trienio, se circunscribe a las obligations particulières des maisons de prêt dentro ya des contraventions et des fautes, ya des délits, con singular tratamiento de casos en que aparezcan involucrados menores, mujeres casadas, sirvientes, vagabundos o militares ${ }^{47}$, en conexión con las incapacidades para contratar ${ }^{48}$. El elenco de autores franceses cuya voz pudiera traerse a colación habría de engrosarse, tan nutrido se adivina, hasta hacer inoperativa la pesquisa, por lo cual mejor parecerá ceñirse a aquellos que veremos invocados en España por su magisterio en orden a la novedosa inteligencia de la cuestión usuaria; así — como digo-, entre otros muchos jurisconsultos, economistas y pensadores, Frédéric Bastiat, el mismo año que lo verá morir — 1850—, desarrolla en

\footnotetext{
${ }^{40}$ MONTESQUIEU, Del espíritu..., pp. 487-489.

${ }^{41}$ GRAVEN, J., «Montesquieu y el Derecho penal», trad. M. A. Moncada, Revista CENIPEC, n 2.25, 2006, pp. 344-345, con referencia a los Pensamientos y escritos inéditos montesquianos, t. I.2, pp. 393, 396.

${ }^{42}$ VOLTAIRE, Diccionario filosofico, trad. C. Lanuza (Nueva York, 1825), t. VII, p. 208.

43 FAIGUET DE VILlENEUVE, J., «Usure», en D. Diderot y J. le Rond d'Alembert (eds.), Encyclopedie, ou dictionnaire raisonné des sciences, des arts et des métiers, par une société de gens de lettres (Paris, 1751-1772), t. XVII, pp. 529-555.

${ }^{44}$ FAIGUET DE VILLENEUVE, «Usure», p. 551.

45 TURGOT, A.-R. J., Memoria sobre los préstamos de dinero, trad. J. E. (París, 1828), pp. 143-194; TURGOT, A.-R. J., Reflections on the formation and distribution of Wealth, trad. s. n. (London, 1793), pp. 81-113.

46 TURGOT, Memoria..., p. 180.

47 BEXON, S., Application de la théorie de la législation pénale, ou code de la sureté publique et particulière (Paris, 1807), ls. III y IV, títs. III, pp. 32-34.

${ }^{48}$ BEXON, Application..., ls. III y IV, títs. III, pp. 27-28.
} 
sus Armonías económicas las más firmes convicciones acerca de la libre estipulación por las partes contratantes de sus recíprocos compromisos ${ }^{49}$.

En Italia, el Marqués de Beccaria no trata de la usura en el retumbante prontuario De los delitos y de las penas, contentándose con un alegato en contra de la prisión de los deudores fallidos ${ }^{50}$, pero sí que, verbigracia, en sus Elementi di economía pubblica se manifiesta a favor de la libertad contractual, «[...] perchè, la libertà delle terre e del loro commercio, gl'interessi dell'imprestito verranno da se al livello dell'interesse della terra ${ }^{51}$. La Ciencia de la legislación de Gaetano Filangieri llega al público a partir de 1780, siendo llevada a la lengua española en 1787: sin ambages, tiene la usura por «[...] otro delito que no se debe castigar»; claro es que «la ley no debería castigarle, pero tampoco debería protegerle», sino que bastaría para precaver todo efecto indeseable con la abolición del apremio personal por insolvencia, que por sí sola retraería a los usureros ante el incremento de riesgo ${ }^{52}$. Por lo demás, incluso en ámbitos eclesiásticos es de notar el esfuerzo conciliatorio, cohonestador de unos justos intereses, por ejemplo, de monseñor Martorelli y del abate Marco Mastrofini con sus respectivos tratados Dell'usura, el primero de $1809^{53}$, el segundo de 1830 y con edición española ya de $1859^{54}$.

En Inglaterra, William Blackstone expone en 1765 los inconvenientes de ahormar el préstamo de intereses, bastando su sometimiento al régimen general contractual para solventar posibles vicios ${ }^{55}$. Y Jeremy Bentham escribe en 1787 un tratadito en Defensa de la usura, vertido al español el mismo año que la Memoria de Turgot, o sea «[...] en favor de la libertad que deben tener los individuos para estipular las condiciones que mas les acomoden en sus transacciones pecuniarias», explayándose en los perniciosos efectos de las leyes anti-usura:

El resultado de mis meditaciones sobre esta materia se reduce para mí á la siguiente proposicion, es á saber, que á ningun hombre que ha llegado á la edad de razon, que tiene un entendimiento sano, y que obra libremente y con conocimiento de causa, no debe impedirse ni aun por consideraciones fundadas en su propia utilidad, que haga como mejor entendiere los contratos y mas le acomoden para procurarse dinero, y que por consiguiente á nadie debe estorbarse que le dé lo que le pida bajo las condiciones que quisiere aceptar ${ }^{56}$.

Luego, en sus Principios de legislación y de codificación figurarán, por consiguiente, catalogados entre los delitos de mal imaginario aquellos «[...] delitos que consisten en hacer algunas convenciones ó tratos inocentes que las leyes han prohibido

\footnotetext{
${ }^{49}$ BASTIAT, F., Armonías económicas, trad. F. Pérez Romero (Madrid, 1858), pp. 183-193.

50 [BECCARIA, C. de], Tratado de los delitos y de las penas, trad. J. A. de las Casas (Madrid, 1774), pp. 201-207.

${ }^{51}$ BECCARIA, C., «Elementi di economía pubblica», Opere (Milano, 1822), v. II, p. 333.

${ }^{52}$ FILANGIERI, C., Ciencia de la legislacion, trad. J. Ribera (Madrid, 1821/1822), t. IV, p. 348.

${ }^{53}$ MARTORELLI DA OSIMO, L., Dell'usura (Roma, 1809).

${ }^{54}$ MASTROFINI, M., Tratado de la usura, trad. M. J. de Ibargüengoitia (Barcelona, 1859). Véase CLAVERO, B., Usura: del uso económico de la religión en la historia (Madrid, 1984), pp. 24-26.

${ }^{55}$ BLACKSTONE, W., Commentaries of the laws of England, adap. R. M. Kerr (London, 1862), t. II, pp. 465-468.

${ }^{56}$ BENTHAM, J., Defensa de la usura, ó cartas sobre los inconvenientes de las leyes que fijan la tasa del interés del dinero, trad. J. E. (París, 1828), pp. 29-30; BENTHAM, J., Reflections on the formation and distribution of Wealth, trad. s. n. (London, 1793), pp. 81-113.
} 
por razones falsas; la usura puede servir de ejemplo», por ello la expulsa sin más del inventario de delitos que apronta con miras a la codificación y la expone a la libertad del comercio $^{57}$ : no otra inferencia cabía esperar del utilitarismo profesado por el filósofo londinense y su ética consecuencialista... La usura, en cuanto delito tradicional contra el patrimonio privado o el comercio público, quedaría sin existencia legal dentro del ordenamiento británico en $1854^{58}$.

De vuelta a España para ir aproximándonos a los aledaños de su Codificación, en el más cierto precedente de esta, el ilustrado Plan de Código criminal de 1787, la Junta de Legislación (que venía trabajando en él desde dos años antes sobre los extractos de Lardizábal para reforma de la Recopilación) mantiene la usura dentro de los «De los delitos contra la propiedad y los bienes de los particulares», último de su parte especial (que antecede a la general y también a la procesal de que consta este boceto ${ }^{59}$. Conviene no perder de vista que, a despecho de la constatación de Casabó en torno a su decisiva influencia en el plan del Código criminal $^{60}$, deja de seguirse en este punto la antedicha postura de un Filangieri, resuelto sin medias tintas por la destipificación.

\section{EL CÓDIGO PENAL DE 1822}

Treinta y tantos años e innúmeras vicisitudes después, llegada la sazón primera del proceso codificador hispano, encuentran el camino expedito al ordenamiento, ahora sí, las florecientes ideas liberales que tanta repercusión habían de tener sobre el concepto de usura y la actitud colectiva hacia ella: un entendimiento del dinero como útil de producción susceptible de alquiler y una repugnancia hacia la injerencia estatal en la contratación privada van a fructificar en la recepción legislativa de 1822. Si un vector patrio avanza con lentitud hacia una ductilidad de trascendencia lenitiva y otro foráneo se pronuncia por la desactivación de la inveterada carga penal, anticipa Landrove que «la postura, respecto de los préstamos usurarios, de nuestro legislador no puede, en modo alguno, calificarse de absolutamente original»; en concreto, como el más difundido en el panorama comparatista, «dentro del régimen francés clásico debemos incluir la orientación mantenida al respecto por nuestro texto punitivo» ${ }^{61}$, a base, pues -dejaba escrito tiempo atrás Víctor Covián-, de copiar al francés, aunque adelgazando de entrada la reactividad penal hacia la intervención mínima antes de remedarle incluso ciertas prescripciones reglamentarias referentes a las casas de préstamo sobre prendas en el adventicio Código de $1848^{62}$.

En efecto, la auroral oportunidad para el escrutinio de semejantes asertos la procura el derrotero genesíaco del primer Código español: la comisión codificadora penal, a la hora de presentar su proyecto ante las cortes constitucionales el 21 de abril de 1821, comienza por exponer la situación del ordenamiento patrio que sus trabajos vienen a modernizar $\mathrm{y}$, en este trance, les importa dejar claro a limine que usuras y

\footnotetext{
${ }^{57}$ BENTHAM, J., Principios de legislacion y condificacion, extrc. F. Ferrer y Valls (Madrid, 1834), t. II, p. 244; BENTHAM, J., Tratados de legislacion civil y penal, extrc. E. Dumont, trad. R. Salas (Madrid, 1821/1822), t. III, p. 8-9, 197.

${ }^{58}$ KERR, R. M., «Additions» a Blackstone, Commentaries..., t. II, pp. 474-475; t. IV, pp. 167-168.

${ }^{59}$ Compruébese en CASABÓ RUIZ, J. R., «Los orígenes de la codificación penal en España: el plan de Código criminal de 1787», Anuario de Derecho Penal y Ciencias Penales, no 22.2, V/VIII-1969, p. 338.

${ }^{60}$ CASABÓ RUIZ, «Los orígenes...», pp. 329, 338.

${ }^{61}$ LANDROVE DÍAZ, El delito..., pp. 42, 53.

${ }^{62}$ COVIÁN, «Usura», p. 641.
} 
logros, en cuanto ejemplo del antiguo y vicioso sistema, de tantas leyes y títulos intempestivos en el dia «[...] que no deben ocupar ningun sitio ni insertarse directamente en un buen Código criminal» ${ }^{63}$; o es esto o —remachará José María Calatrava, portavoz de la comisión $\mathrm{y}$, a buen seguro, artífice directo de no pequeña porción del borrador preparatorio- es que ya «[...] están comprendidos ó embebidos en otras disposiciones del proyecto» ${ }^{64}$. De tal manera, este, en consecuencia con tales ideas, recibe el expurgo político-criminal, por mimetismo de la postura adoptada por el Código napoleónico ${ }^{65}$ - tacha de nuevo Landrove-, sin dar entrada a otro ilícito tocante al préstamo de caudales, ó géneros, ó efectos que el previsto entre el grupo «De los delitos contra la propiedad de los particulares», con mayor precisión integrante «De las estafas y engaños», al sancionar el abuso en su perjuicio de la debilidad del hijo de familia menor de veinticinco años o del incapacitado física o moralmente y sujeto a interdicción judicial, con una redacción ${ }^{66}$ que apenas difiere de la que, tras un debate parlamentario de algo menos de tres meses sobre el conjunto, accederá a la postre a lo que será primer fruto peninsular de la codificación ${ }^{67}$ : aunque al fin ya no se especifica la mayoría de edad en los veinticinco años (la comisión civil proyectaba rebajarla a los veinte, por eso se prefirió dejar abierta la cuestión ${ }^{68}$ ), sigue siendo esa cifra -y hasta 1889- la divisoria clásica del Derecho castellano ${ }^{69}$. Acaso también el tipo genérico de la estafa pudiera, con otras circunstancias, acoger supuestos de préstamos bajo condiciones leoninas, pero siempre que mediare algun artificio, engaño, superchería ${ }^{70} \ldots$, etcétera, nunca por pura necesidad del mutuatario que le constriña a consentir. Por lo tanto, ya la usura no se inserta directamente y cuanto de sus inmediaciones aún resulte perseguible permanece ahora comprendido o embebido en otros tipos: no se pase por alto que es esta la vez primera que escuchamos aseveración de semejante alcance a este lado de la raya de Francia... La familia criminológica persiste, con todo, y se mantendrá en adelante así, entre los delitos contra la propiedad, pese al inequívoco componente de lepra social, de funestas consecuencias para el orden y la paz pública ${ }^{71}$, pese al sincrónico ataque o amenaza contra un bien colectivo difuso que remite a la salubridad, a la justicia del mercado.

\footnotetext{
${ }^{63}$ Diario de las Sesiones de Córtes. Legislatura Extraordinaria [DSCLE] (Madrid, 1871), t. I, apd. al n ${ }^{\circ}$ 38, ses. 1-XI-1821, pp. 482-483.

${ }^{64}$ DSCLE, t. II, no 60, ses. 23-XI-1821, p. 927.

${ }^{65}$ LANDROVE DÍAZ, El delito..., p. 30; por igual, pp. 64, 258.

66 «Proyecto de Código Penal, presentado á las Córtes por la comision especial nombrada al efecto» [PCP 1821], en DSCLE, t. I, apd. al n 38 , ses. 1-XI-1821, pp. 485-550, arts. 775 y 776.

67 «Ley del Código Penal», de 8 de junio de 1822, en Coleccion de los Decretos y Órdenes Generales Expedidos por las Córtes 9, decr. 56, pp. 211-381 [CP 1822], art. 771: «Cualquiera que abusando de la debilidad ó de las pasiones de un menor de edad que sea hijo de familia, ya esté sujeto á tutor ó curador, ó de cualquiera que esté en interdiccion judicial por incapacidad fisica ó moral, hubiere conseguido hacerle firmar alguna escritura de obligacion, ó de liberacion ó finiquito por razon de préstamos de caudales, ó géneros ó efectos, cualquiera que sea la forma bajo la cual se haya contratado; ó hubiere percibido de dichas personas abusando igualmente de sus circunstancias, alguna cosa vendida, empeñada, cambiada, alquilada ó depositada, sin autoridad legítima, sufrirá un arresto de diez dias á un mes, y una multa de diez á cien duros»; art. 772: «[...] podrán los reos ser puestos bajo la vigilancia de la autoridad local por el tiempo de dos á cinco años, con obligacion de dar fiador abonado de su conducta; y no encontrándole, se doblará la pena de reclusion, y se convertirá en esta la de arresto».

${ }^{68}$ DSCLE, t. III, n ${ }^{\circ} 129$, ses. 1-II-1822, p. 2100.

${ }^{69}$ V. gr., $P$, VI.19.2.

${ }^{70}$ CP 1822, art. 766, derivado del PCP 1821, art. 770.

71 BURGOS CRUZADO, A., «La usura y sus remedios», Revista General de Legislación y Jurisprudencia, no 160, 1932, p. 317; LANDROVE DÍAZ, El delito..., p. 35.
} 
Sometido el proyecto a informe, con miras a instruirse codificador y legislador, entre los tribunales, cuerpos literarios y aun particulares ilustrados, algún reparo surge frente al descarte delictivo del lucro inmoderado en el préstamo: así, la Universidad de Orihuela, si bien inclinada al elogio en general, nota que falta su punición; y el Colegio de Abogados de Granada, «[...] aunque conviene con la comisión en lo que dice en su discurso acerca de omitirse» este y otros comportamientos, «[...] manifiesta que la idea propagada de que no se castiga esto en el Código, bastaria para desacreditarlo, segun el estado de las costumbres» ${ }^{72}$; no obstante, el resto de corporaciones nostálgicas de los tipos más castizos se centrará con preferencia en otros tales como herejía, sacrilegio, sodomía, bestialidad, incesto, suicidio, juego, vagancia, sortilegio ${ }^{73} \ldots$ El propio Calatrava, centrado en la usura y préstamos no gratuitos, ahínca todavía: «la comision cree que esto no merece el nombre de delito, y que no debe ocupar lugar en el Código penal» ${ }^{74}$. Aparte, ante la denuncia del Colegio de Abogados madrileño de haber tomado el Código Penal francés por modelo para el nuestro, replica ante la Cámara con una profesión de influjos, incómodo ante el achaque de sometimiento servil al supuesto patrón único: «la comision confiesa ingénuamente que ha tomado muchas cosas del Código francés, así como de las obras de Bentham, de Filangieri, de Bexon, y de los demás que ha tenido á la mano» ${ }^{75}$. De cierto, nos consta que al menos entre los tres expresamente mencionados el sentir era concorde en la criba de la tipología usuraria. En cuanto original aporte, pone Groizard de relieve cómo, aunque a decir verdad «la primera vez que en un cuerpo legal se escribió algo parecido [...] fue en el Código francés de $1810 \gg^{76}$, que conjura el abuso de las necesidades, de las debilidades ó de las pasiones de un menor ${ }^{77}$ (pero la protección sobre los hijos de familia ya era regla general en las Partidas y en la Novísima Recopilación ${ }^{78}$ ), no es menos cierto que el Código de 1822 se separó de él cuando «[...] igualó en los efectos de la imputación los incapacitados á los menores» en el concepto de víctimas ${ }^{79}$, brindando nuevo criterio para otra corriente legislativa, menos secundada, pero rastreable de hecho en lo sucesivo.

\section{DEL CÓDIGO DE 1848 AL DE 1870}

En principio, el segundo retorno de Fernando VII al trono de sus mayores implica también otro retorno a la herrumbrosa legislación pretérita hasta que casi llegue a mediar la centuria, pero las cosas no se muestran tan sencillas y, en ese ínterin, conviene parar mientes tanto sobre las soluciones practicadas en el tráfico y en sede forense con recurso al arbitrio judicial ${ }^{80}$ como sobre los tanteos de las diversas labores codificadoras cuyos pormenores nos han llegado. Eugenio de Tapia en su Febrero

${ }^{72}$ DSCLE, t. II, $\mathrm{n}^{\circ} 60$, ses. 23-XI-1821, p. 922.

${ }^{73}$ DSCLE, t. II, no 60, ses. 23-XI-1821, pp. 921-924 ; ibidem, , t. III, no 129, ses. 1-II-1822, p. 2099.

${ }^{74}$ DSCLE, t. III, $\mathrm{n}^{\circ} 129$, ses. 1-II-1822, p. 2099.

${ }^{75}$ DSCLE, t. II, no ${ }^{\circ} 60$, ses. 23-XI-1821, p. 924.

${ }^{76}$ GROIZARD Y GÓMEZ DE LA SERNA, A., El Código Penal de 1870 concordado y comentado (Burgos/Salamanca, 1870/1899), t. VII, p. 292.

${ }_{77}$ Código penal francés, traducido al castellano por orden de S. M. el emperador Maximiliano I, trad. M. Zavala et al. (Méjico, 1866), p. 86 (art. 406).

${ }^{78}$ P, V.1.4; NRLE, X.1.17.

${ }^{79}$ GROIZARD Y GÓMEZ DE LA SERNA, El Código..., t. VII, p. 297.

${ }^{80}$ Véase, v. gr., SÁNCHEZ GONZÁLEZ, M. D. M., La codificación penal en España: los códigos de 1848 y 1850 (Madrid, 2004), pp. 25-31; COBO DEL ROSAL, G., «Los mecanismos de creación normativa en la España del siglo XIX a través de la codificación penal», Anuario de Historia del Derecho Español $[A H D E], \mathrm{n}^{\circ}$ 81, 2011, p. 931; o BARÓ PAZOS, J., «El derecho penal español en el vacío entre dos códigos (1822-1848)», AHDE, $\mathrm{n}^{\circ}$ 83, 2013, pp. 108-113. 
novísimo, al concluir los años veinte de la centuria, reputa lícitas y corrientes las usuras compensatoria y punitoria, en tanto que la superación de la tasa legal - y consuetudinaria en su interpretación extensiva- del seis hace caer el contrato en nulidad por interés lucratorio; por lo tanto, entiende vigente y no soslayable la regulación ancestral, sin exclusiones penales, «pues no sirve alegar que las leyes no están en uso para no observarlas, como lo mandan la $1^{\text {a }}$ de Toro, y la [...] Nov. Rec., siendo preciso que esten derogadas expresamente» ${ }^{81}$. En 1838, al abogado Hernández de la Rúa le «[...] parece muy bien la doctrina prohibitiva de nuestras leyes hasta cierto punto de la cantidad, que en el mutuo puede estipularse por el uso de lo prestado», en virtud de «[...] que en la mayor parte de los contratos de esta especie la causa inductiva del consentimiento, es la de la miseria, y la de las necesidades de presente»; el sistema de tasa legal recopilado y por él resumido, busca, pues, un término medio entre la libertad de los contrayentes y la protección a la indigencia, «mas á pesar de estas trabas es poco menos que imposible contener los excesos de esta polilla del estado [...], por más que los economistas quieren justificar este género de comercio con sus teorías» ${ }^{82}$, merecedor por tanto de represión penal con arreglo a aquella ley. Sin embargo, un par de años más tarde, en 1840, Del Valle Linacero amonesta que «habiendo cambiado totalmente las opiniones sobre lo que se ha llamado usura, ha caducado la legislacion acerca de ella; y es de toda necesidad y urgencia formar otra adecuada ${ }^{83}$.

A poco de comenzar la década, en la edición corregida y aumentada de su Diccionario razonado, Joaquín Escriche, persuadido y persuasivo liberalizador en la cuestión del interés redituable (por supuesto, del compensatorio y el punitorio, consentidos hasta la tasa legal, pero además del lucrativo), atestigua préstamos en el Madrid contemporáneo de hasta el mil ochocientos por ciento anual ${ }^{84}$, mas entiende que cualquier coto incluso a tan monstruosa codicia (que nos repugna) no hará, de acuerdo con el argumentario de Montesquieu o Faiguet ${ }^{85}$, sino - paradójicamente- fomentarla y que, por ende, «[...] el precio del uso de dinero debe abandonarse al curso de los acontecimientos y a las convenciones particulares» ${ }^{86}$. La sola excepción se reduce al abuso sobre los hijos de familia (ya prefigurado, según lo avandicho, con genérico ensanche en nuestra centenaria legislación ${ }^{87}$ ), puesto que en él el delito consiste ya «[...] en facilitar y fomentar por un vil interés los desórdenes de los jóvenes, y poner a estos en la alternativa de arruinarse o de deshonrarse»: en consecuencia, «[...] estos préstamos son absolutamente nulos, y no pueden los usureros pedir los intereses ni aun el capital $[\ldots]\rangle^{88}$. Al margen de estas conclusiones personales, registra por el momento los usos del día: extendida consuetudinariamente la tasa mercantil del seis por ciento (reiterada por Carlos III, Carlos IV y aun el Código de Comercio de 1829) también al

\footnotetext{
81 TAPIA, E. de, Febrero novísimo, ó Librería de jueces, abogados y escribanos, refundida, ordenada bajo nuevo método, y adicionada con un tratado del juicio criminal, y algunos otros (Valencia, 1828/1831), t. II, p. 471; t. V, p. 38, t. VII, p. 170.

${ }^{82}$ HERNÁ[N]DEZ DE LA RÚA, V., Lecciones de Derecho español (Madrid, 1838), t. II, pp. 227-229.

83 DEL VALLE LINACERO, F., y CHAVARRÍA Y MONTOYA, A. de, Leyes penales vigentes actualmente en España, recopiladas de nuestros códigos, ordenanzas y colecciones de decretos. Reflexiones sobre los vicios de la administracion de Justicia, abusos de algunos curiales, y necesidad de una pronta y eficaz reforma de nuestros Códigos (Madrid, 1840), p. 52.

${ }^{84}$ ESCRICHE, Diccionario..., t. II, p. 515.

${ }^{85}$ ESCRICHE, Diccionario..., t. II, pp. 498-499, 515-516, v. gr.

${ }^{86}$ ESCRICHE, Diccionario..., t. II, p. 516.

${ }^{87}$ Cfr. nota 78.

${ }^{88}$ ESCRICHE, Diccionario..., t. II, p. 516.
} 
mutuo entre particulares ${ }^{89} \mathrm{y}$ «[...] habiendo caducado ya las penas $[\ldots]$ prescritas en las leyes, porque no se prescribieron sino en el concepto de que el dar dinero á logro ó interés, cualquiera que éste fuese, era gran pecado [...], no se pueden ya imponer en el dia por los tribunales [...] $»^{90}$; pero, sin hacer suya el ordenamiento la aspiración liberalizadora, aún habrán estos de seguir reprendiendo de alguna manera las intemperancias redituales,

Asi es que en caso de exceso y de querella de parte, no se suele hacer otra cosa por la primera vez, que condenar al logrero en la restitución del exceso y pago de costas; por la segunda parece muy natural la pena de perder todos los intereses establecida en el Fuero Juzgo; y por tercera es muy conforme la pena de pérdida de los intereses y otro tanto prescrita en el Fuero Real; pero nunca la de perder el capital, pues ni las mismas Partidas la imponian ${ }^{91}$.

En cambio, a la altura de 1843, los Elementos de Gómez de la Serna y Montalbán, junto a la tasa del Código de Comercio, en lo penal todavía reproducen sin más la punición esgrimida por la Novísima para la usura lucratoria ${ }^{92}$. Obra asimismo del año 1843, García Goyena, en su Código criminal español segun las leyes y práctica vigentes comentado y comparado con el Penal de 1822, el francés y el inglés, ilustra - mas sin cohibir su particular criterio de política criminal - cómo [...] el interés del dinero está á la órden del dia, tanto respecto del Gobierno como entre particulares, á pesar de las leyes prohibitivas; y los tribunales suelen admitir el convencional de seis por ciento, y rebajar el que procede simplemente de condenacion ó sentencia [...] Con todo, públicamente y por escrituras solemnes se estipula un interés mucho mayor, que dificulto sea sancionado por los tribunales en caso de litigio. Hay todavía más, y esto merece una pronta y ejemplar represión. / Personas oscuras, verdaderos vampiros de la sangre de los necesitados, prestan sobre alhajas ó prendas de valor, exigiendo al menos el interés mensual de un real por cada duro; y la policía y los fiscales lo saben, y todos callan! ${ }^{93}$

Opuesto tanto a la absoluta proscripción del interés — presume de alinearse con el modelo civil francés ${ }^{94}$ - como a las descritas demasías, no termina de resolverse entre la limitación legal o el margen corriente para la actuación judicial que valore el daño emergente, el lucro cesante o hasta un moderado resarcimiento por la exposición a perder el capital: «es preciso fijar el interés para los casos en que proceda de derecho ó simplemente por sentencia; y ver si convendrá tambien señalar un máximo para el

${ }^{89}$ ESCRICHE, Diccionario..., t. II, p. 513; ESCRICHE, J., Elementos del Derecho patrio (Madrid, 1840), p. 234.

${ }^{90}$ ESCRICHE, Diccionario..., t. II, p. 514.

${ }^{91}$ ESCRICHE, Diccionario..., t. II, p. 514 (sin escrupulosa observancia de nuestras leyes, que no deja de consignar, ibidem, t. III, p. 559)

${ }^{92}$ GÓMEZ DE LA SERNA, P., y MONTALBÁN, J. M., Elementos de Derecho civil y penal de España, precedidos de una reseña histórica de la legislacion española (Madrid, 1843), t. II, pp. 142-143, 296.

${ }^{93}$ GARCÍA GOYENA, F., Código criminal español segun las leyes y práctica vigentes comentado y comparado con el Penal de 1822, el francés y el inglés (Madrid, 1843), t. I, p. 360. Corrobora tales noticias Pío Laborda en su edición anotada del Código civil francés, ed.-trad. P. Laborda y Galindo (Madrid, 1850), t. I, p. 352.

${ }^{94}$ Código civil francés, ed. cit., art. 1905: «Se permite pactar interés por el simple préstamo, sea de dinero, sea de géneros ú otras cosas muebles»; art. 1907: «El interés es legal ó convencional. El legal se fija por la ley; el convencional puede esceder al de la ley siempre que esta no lo prohíba» (la fijación, operada por ley de 3 de septiembre de 1807 en un cinco por ciento). Aducido en GARCÍA GOYENA, Código..., t. I, p. 358. 
convencional, ó dejar á la ilustrada equidad de los jueces que lo moderen y reduzcan al común y corriente en la plaza, cuando aparezca que se ha abusado de la necesidad ó simplicidad del deudor ${ }^{95}$, sin perjuicio de la pronta y ejemplar represion, como quiera que fuere, de aquellos verdaderos vampiros de la sangre de los necesitados... De momento, el Febrero de 1852, subscrito también por el propio Goyena como uno de sus actualizadores, informará en concomitancia con Escriche de que, en vísperas del Código, «[...] las penas marcadas por nuestras leyes á la usura [...] por otra parte habian sido sustituidas últimamente por la práctica, que condenaba al usurero por primera vez á la restitucion del esceso del interés y pago de costas; por la segunda, en la pérdida de los intereses, y por la tercera, en el duplo de estos mismos ${ }^{96}$ : plasmaran lo que plasmaran en sus tratados, no solo Goyena o Escriche, pero ni Tapia o La Serna y Montalbán podían pensar ya seriamente en la oportunidad del mecanismo confiscatorio como respuesta penal.

De lege ferenda, en el Proyecto de Código Criminal elevado a Fernando VII en 1830 por la junta designada un año antes falta cualquier acomodo particular de los métodos usurarios, que ni aun cabe envolver dentro «De las estafas y engaños» por requerir el tipo un perjuicio propiciado por falsos supuestos o vanas promesas ${ }^{97}$... El Proyecto que otra junta actuante entre 1833 y 1834 presenta en esta última fecha copia ese mismo precepto ${ }^{98}$, validando con ello la apreciación de Casabó de que «el proyecto de 1834 es el de 1830 con leves retoques que no afectan en manera alguna a sus principios informadores ${ }^{99} \mathrm{ni}$-cabe añadir- a menudo siquiera al tenor de sus cláusulas, como sucede en este supuesto, tan solo modificado en la segunda versión con penalidad algo más gravosa: la inhibición tutelar toca el máximo y la usura en cualesquiera de sus manifestaciones brilla por su ausencia. Entremedias, el Proyecto de Sainz de Andino, en 1831, aprestaba un tipo de abuso de la falta de inteligencia, ligereza, debilidad o pasiones de un menor de edad para, entre otras posibles finalidades, la firma de escrituras de préstamo con resultado de perjuicio y lesión «[...] por un título ilegal o bajo condiciones reprobadas en derecho» ${ }^{100}$, reelaboración del abuso de menor establecido en 1822 como única contravención usuraria que se afianzará en el venidero logro del codificador penal, haciendo buena otra vez la diagnosis del mismo Casabó, ahora con hincapié en que «el interés del proyecto no reside en su originalidad, pues en muchas ocasiones sigue de modo más o menos disimulado al Código Penal de 1922, sino en el hecho de que parece constituir el eslabón que une muchas disposiciones de este Código con el de $1848{ }^{101}{ }^{\text {. Lo cierto es }}$ que aquel prístino corpus trienal y el texto de Andino comparten ese supuesto usurario en perjuicio de menor que perdurará en el futuro, sí, pero ya con la propincuidad de otra tipología de algún modo afín cuya presencia codificada, además, estrena ahora Andino:

\footnotetext{
${ }^{95}$ GARCÍA GOYENA, Código..., t. I, pp. 360-361.

96 GARCÍA GOYENA, F., y AGUIRRE, J., Febrero ó Librería de jueces, abogados y escribanos (Madrid, 1852), t. II, p. 248.

${ }^{97}$ El Proyecto de Código Criminal de 1830, ed. J. R. Casabó Ruiz (Murcia, 1978), art. 262.

${ }^{98}$ El Proyecto de Código Criminal de 1834, ed. J. R. Casabó Ruiz (Murcia, 1978), art. 367.

${ }^{99}$ CASABÓ RUIZ, J., «Estudio preliminar» a El Proyecto... de 1830, p. 7.

${ }^{100}$ El Proyecto de Código Criminal de 1831 de Sainz de Andino, ed. J. R. Casabó Ruiz (Murcia, 1978) [PCC 1831], art. 1050: «Los que abusando de la falta de inteligencia, ligereza, debilidad o pasiones de un menor de edad, les hicieren consentir, otorgar o firmar escrituras de préstamo, letras de cambio, pagarés, recibos u otros documentos de obligación o de pago, satisfacción o exoneración, de que resultare perjuicio y lesión al mismo menor por un título ilegal o bajo condiciones reprobadas en derecho, serán castigados con la pena de seis meses a dos años de reclusión y la multa del equivalente del fraude que hayan cometido».

${ }^{101}$ CASABÓ RUIZ, J., «Estudio preliminar» a El Proyecto... de Andino, p. 3.
} 
la de los excesos en los préstamos sobre prendas, excesos aquí materiales y no puramente formales como lo serán en $1848^{102}$.

Los miembros de la Comisión General de Codificación sobre Código Penal actuante entre octubre de 1844 y diciembre de 1845 comparten más o menos su repulsión por la rapacidad usurera con el convencimiento de que la hora reclama una cierta transigencia en el aprontamiento y la calidad de la intervención estatal. Expone Claudio Antón de Luzuriaga a sus compañeros la apreciación de que en los trabajos de sus homólogos civiles «[...] ha desaparecido la usura, pero con la condición de que en la estafa debemos tener muy presente los abusos que se pueden cometer por los logreros o usureros» ${ }^{103}$, en especial «[...] los abusos que se pueden cometer valiéndose de la debilidad de los menores», caso el de mayor alarma, tanto que requiere la insistencia: «yo quisiera que se dijera algo de los menores, porque aunque sea legítimo el interés si éste es ilimitado se concibe bien el abuso que puede hacerse de un menor para engañarle» ${ }^{104}$; sin acordarse de los incapaces físicos o morales del Código antecedente, a Goyena se le ocurre que «puede haber entre otros casos de debilidad el de un empleado que abuse del estado de embriaguez o enfermedad de otro», otro interlocutor -Cirilo Álvarez- ejemplifica la superioridad de un abogado contratante con un labriego («aquí hay diferencia de razón»), pero Luzuriaga zanja la incipiente controversia mediante el cotejo comparatista de que «[...] de los menores hablan todos los Códigos y de los borrachos, ninguno», de suerte que «se puso a votación [...] y se acordó se redujese a los casos de simulación de menor y debilidad» ${ }^{105}$. Sin tales desvalimientos que proteger, en el resto de casos, se arguye que «esos logreros tienen ya una pena cual es la de perder con frecuencia su dinero» ${ }^{106}$, lo cual insinúa cierta reconducción al terreno meramente privado o al engranaje del mercado, de manera que, ante «[...] esos préstamos en que se lleva nada menos que una peseta por cada duro», concuerdan en que «al Código penal corresponde poner las penas, pero eso corresponde al Código civil» ${ }^{107}$. Redactada esta parte por José María Clarós, aduce en su tarea los ejemplos francés y brasileño ${ }^{108}$, lo que encuentra particular confirmación en unos tipos desconocidos por el Código de 1822, los de las casas de préstamos sobre prendas: atentos los junteros a las «[...] circunstancias que trae el Código francés (se leyeron)» ${ }^{109}$, recogen de él la falta de licencia, la de libros y resguardos, pero rechazan punir la enajenación de la prenda contra el pacto que llevaba bosquejada el susomentado ponente de esta sección Clarós ${ }^{110}$.

102 PCC 1831, art. 1055: «Los que se ocuparen de prestar sobre prendas a réditos excesivos y con infracción de las disposiciones del Código civil sobre los préstamos con interés, serán castigados con la pena de cuatro meses a un año de arresto y una multa equivalente al doble de las cantidades que hubieren prestado en esta forma».

${ }^{103}$ En «Actas de la Comisión General de Codificación sobre Código Penal (1844-1845)», apud LASSO GAITE, J. F., Crónica de la Codificación española. 5. Codificación penal (Madrid, 1970), v. II, apd. VI [ACGCP], a. 26, ses. 28-V-1845, p. 805.

${ }^{104}$ ACGCP, a. 29, ses. 3-VI-1845, p. 828.

105 ACGCP, a. 29, ses. 3-VI-1845, p. 829.

106 ACGCP, a. 26, ses. 28-V-1845, p. 805.

107 ACGCP, a. 36, ses. 11-VI-1845, p. 886.

${ }^{108}$ ACGCP, a. 29, ses. 3-VI-1845, p. 827.

${ }^{109}$ ACGCP, a. 36, ses. 11-VI-1845, p. 886.

110 ACGCP, a. 36, ses. 11-VI-1845, pp. 886-887: «Artículo 15: El que estableciere casa de préstamos sobre prendas u otras seguridades sin licencia de la autoridad, sufrirá una multa de 25 a 250 duros»; «artículo 16: El que estableciese casa de préstamos sobre prendas u otras seguridades, y no llevase libros formales en que sin claros ni entrerrenglonados consten las cantidades prestadas, los plazos e intereses, los nombres y domicilios de los que reciban las cantidades, la naturaleza, calidad y valor de los objetos 
Llevado el Código al Congreso en demanda de habilitación al gobierno para decretarlo, deliberaba aquel sobre la totalidad entre el 10 y el 16 de marzo y, precisamente, en la primera de tales sesiones el diputado gallego José María Pardo Montenegro abre el debate con sus escrúpulos ante la desregulación penal de la usura: hijo del siglo, comienza por conceder «[...] que puede exigirse un interés moderado por el dinero»,

Pero yo no hablo de eso, yo hablo de los réditos excesivos y exorbitantes que los usureros ó logreros, como llaman nuestras leyes, perciben de los infelices á quienes dan dinero prestado, arruinándolos y empobreciéndolos. De esta usura hablo yo; de esta usura anatemizada por la recta razon, por el derecho canónico, por la sana moral y por nuestras leyes. [...] / Pues bien, señores; en el Código penal de una Nacion que tiene la dicha de ser católica, apostólica, romana, según el art. 11 de la Constitucion política de la Monarquía, en su Código penal, repito, no se cuenta en el número de los delitos, ni aun en el de las faltas siquiera, la usura; por consiguiente, no puede ser penada. De hoy más podrán los logreros ó usureros, bajo la salvaguardia de las leyes, al amparo de la impunidad, exigir el 20, el 40, el 100 y aun más por 100 de los intereses sobre el dinero que presten ${ }^{111}$.

Es el ministro Lorenzo Arrazola el primero en responderle con la motivación que asistía al gobierno para aprestar

[...] que hoy venga preterido en el Código penal, porque no queriendo prejuzgar la cuestion por lo mismo que se roza con la moral, en su juicio ilustrado los autores del Código han creido sin duda lo que creo yo, porque [...] esta es la ciencia, la opinión comun, que la usura no es delito, sino condicion irritante del contrato de mútuo. Cuando en el Código civil, se determinen las circunstancias del mútuo, podrá venir como condicion irritante la usura, y tendrá su sancion civil, la de revocar ó anular el contrato ó la que corresponda. Pero aquí no hay necesidad de elevarla á delito, prejuzgando así una cuestion que es menester esperar á que se fije bien por la experiencia y por la ciencia ${ }^{112}$.

Y, desde el frente común, por la Comisión codificadora es Claudio Moyano quien da la réplica oponiendo

[...] que hoy apenas habrá un hombre que teniendo dinero no lo emplee en alguna operacion mercantil. Y siendo esto tan general, es más difícil que deje de darse el caso de no sufrir perjuicio por prestar el dinero á otro, y esto es una razon para que la comision no considere eso como un delito [...]: el prestar dinero á interés no es malo, no se condena, y desde hoy puede hacerlo todo el que quiera; y cuando sean muchos los que ofrezcan dinero no serán tan grandes los intereses como cuando eran pocos, pues

dados en prenda, y los demás requisitos que exijan los reglamentos, sufrirán la multa de 100 a 1000 duros, y la pérdida de las cantidades prestadas»; «artículo 17: El prestamista que no diere resguardo del préstamo, perderá la cantidad prestada, y sufrirá una multa equivalente desde el duplo al quíntuplo de la cosa empeñada»; sin discusión se suprime el «artículo 18: El que habiendo recibido prenda por préstamo la distrajere o enajenare contra el pacto o disposición legal sufrirá la pena del duplo al quíntuplo del valor de la prenda».

${ }^{111}$ Diario de las Sesiones de Cortes. Congreso de los Diputados. Legislatura de 1847 a 1848 (Madrid, 1877) [DSC 1847-48], t. III, ses. 79 (10-III-1848), p. 1706.

${ }^{112}$ DSC 1847-48, t. III, ses. 79 (10-III-1848), p. 1707. 
hasta el ser pequeño número contribuia á que fuesen inmorales. Esto es lo que hemos creido que se debia adoptar para evitar los abusos que se cometian. / [...] Esto no quiere decir que la comision apruebe los abusos ${ }^{113}$.

Ahora bien -y, sobre tal confianza en la autorregulación del mercado, brinda Moyano con esto la clave de la propuesta liberalizadora-, «[...] como no se puede saber cuál es el perjuicio que va á sufrir uno que presta el capital, ni qué ganancias deja de hacer con su empleo en otra cosa por sí propio, no se puede fijar el tanto por 100, y por consiguiente no se puede decidir desde dónde principia el abuso» ${ }^{114}$. Y aun Manuel de Seijas Lozano, factor de la mayor parte del Código, se siente obligado a salir al quite con añadidas razones en apoyo de la opción:

[...] ¿es delito la usura hoy en España? [...] Si lo es, ¿cómo se han de entender las disposiciones del Código mercantil? En él se previene que cuando de un contrato aparezca, ó por cualquier medio se averigüe, que ha habido más interés que el 6 por 100, el tribunal lo reduzca á este 6 por 100, por manera que el interés no pase de esto. Establece tambien el Código de comercio que se llevará interés de interés siempre que la cuenta se pasara á cuenta nueva, es decir, que se reduzca á nuevo contrato. Por manera, señores, que la usura, que consiste en llevar más réditos que el 6 por 100, ó en llevar interés de interés, está autorizada por el Código de comercio; y cuenta, señores, que se dió el año 30, en tiempo de un monarca absoluto, y desde entonces acá nadie ha tenido escrúpulo sobre esto ${ }^{115}$.

De hecho, Seijas, que repudia el modelo francés y elogia el napolitano y, más que ninguno, el brasileño ${ }^{116}$, se precia, con todo, de presentar un Código puramente español tras haber consultado la legislación y la jurisprudencia del país, «[...] esa jurisprudencia que se ha mantenido siempre por los tribunales» ${ }^{117}$; y el presidente de la comisión parlamentaria dictaminadora en la Cámara, Pedro José Pidal, insiste en «[...] que en este proyecto no se ha hecho más que recopilar la práctica, el derecho existente en los tribunales, escribirle, redactarle y uniformarle» ${ }^{118}$. Pese a las proclamaciones, más de uno continuaba sin ver «[...] la conveniencia de este Código, [...] su conformidad y su analogía con las costumbres, con las tradiciones, con los hábitos del pueblo español» ${ }^{119}$. Entre ellos, reacio incluso al procedimiento codificador y, ya que se haya de pasar por él, inclinado a que lo civil precediese a lo criminal, Pedro Gómez de la Serna, conviniendo en que no sea delito la usura, interpela con alguna irreflexión o artería a los señores de la comision arguyendo que, en tal hipótesis, no debería mantenerse en el ordenamiento civil la pena de nulidad, infiriendo así la tacha de «[...] que nuestras leyes civiles van a estar en discordancia con el Código penal» ${ }^{120}$. Dirime Pidal: «si fuera cierta la teoría del Sr. Laserna, tendríamos que incluir en el Código penal todos los casos de nulidad de contratos que provienen de un hecho de la parte, y eso no lo quiere S. S. ni nadie tampoco» ${ }^{121}$. Algún otro diputado protesta cómo «[...]

\footnotetext{
${ }^{113}$ DSC 1847-48, t. III, ses. 79 (10-III-1848), p. 1710.

${ }^{114}$ DSC 1847-48, t. III, ses. 79 (10-III-1848), p. 1711.

115 DSC 1847-48, t. III, ses. 79 (10-III-1848), p. 1718. Véase Código de Comercio decretado, sancionado y promulgado en 30 de Mayo de 1829 (Madrid, 1829), arts. 397 a 399, 401.

${ }^{116}$ DSC 1847-48, t. III, ses. 79 (10-III-1848), p. 1715.

${ }^{117}$ DSC 1847-48, t. III, ses. 79 (10-III-1848), p. 1715.

${ }^{118}$ DSC 1847-48, t. III, ses. 82 (14-III-1848), p. 1774.

${ }^{119}$ DSC 1847-48, t. III, ses. 82 (14-III-1848), p. 1779.

${ }^{120}$ DSC 1847-48, t. III, ses. 82 (14-III-1848), p. 1767.

${ }^{121}$ DSC 1847-48, t. III, ses. 82 (14-III-1848), p. 1775.
} 
esta no es la jurisprudencia práctica de los tribunales; porque no se les ha oido sobre penas y delitos; porque no han intervenido en la formacion de este Código los jurisconsultos prácticos [...], y no han intervenido personas competentes como catedráticos y canonistas» ${ }^{122}$. Cabalmente para paliar esta carencia, durante el lapso entre la autorización parlamentaria del decreto ejecutivo y la entrada en vigor el 1 de julio, el gobierno se aviene a escuchar advertencias y dudas suscitadas por el flamante articulado: el informe de la Audiencia de Valencia nos entera, en general, cómo, «[...] habida cuenta de que ciertos delitos han dejado de estar tipificados, [...] se estaba estableciendo un sobreseimiento sin costas» ${ }^{123}$ en cuanto mecanismo para aplicación de la ley más favorable al reo ${ }^{124}$; asimismo y ya con alusión concreta, la Audiencia de Zaragoza entiende un problema importante el tránsito entre la antigua legislación y la moderna, pues hay delitos que dejan de serlo — señalando el uso de armas prohibidas, la usura y la hechicería-: «[...] lo más lógico es el sobreseimiento de acuerdo con el espíritu del Código y para no provocar costes» ${ }^{125}$, inteligencia que obtendrá el respaldo de la Comisión ${ }^{126}$, interpelada por similares inquietudes desde las Audiencias de Barcelona, Madrid o Cáceres ${ }^{127}$. La de Granada, ante la destipificación de la usura, «[...] se dirige a solicitar una aclaración acerca de su vigencia en al ámbito civil» ${ }^{128}$, a lo que los comisionados responden «[...] cómo la legislación, en su deseo de prohibir la usura, había indicado efectos distintos civiles y penales, y penalmente el Código de comercio había suprimido la usura para los comerciantes por lo que era un contrasentido mantenerla para los que no lo fueren. Respecto del fondo de la consulta, considera que se trata de un tema civil» ${ }^{129}$. Con tal inteligencia, el Febrero de 1852 advierte que «[...] por el silencio del nuevo Código penal no deben considerarse derogadas nuestras antiguas disposiciones sobre los efectos civiles de los contratos en que interviene un interés escesivo, por lo que [...] son nulas y no traen aparejada ejecucion las escrituras de los contratos en que interviene usura» ${ }^{130}$, si bien no más que por unos cuantos años, hasta el de 1856 que verá eliminarse, con la consecuente inatacabilidad civil, toda tasa al establecimiento de intereses en el préstamo simple o mutuo ${ }^{131}$.

Pero restituyámonos al ordenamiento criminal y contemplemos la residual representación en él desde 1848 de formas o adyacencias de la usura: un orden de delitos referidos a las casas de préstamos que acaso pudieran haberse acomodado en reglamentos de policía y ese otro remanente de auténticas prácticas usurarias en que ha ido a subsumirse lo que de punitivamente sancionable pretende dejarse de ellas. Con palabras del Febrero de 1852, «en el nuevo Código penal, no se pena espresamente la usura, aun cuando se castigan en él los fraudes y exacciones escesivas ó simuladas ${ }^{132}$, aludiendo, por descontado, al ya conocido de abuso de la impericia o pasiones de un menor - quien, de resultas, se obliga mediante préstamo en su propio perjuicio-,

\footnotetext{
${ }^{122}$ DSC 1847-48, t. III, ses. 82 (14-III-1848), p. 1767.

${ }^{123}$ SÁNCHEZ GONZÁLEZ, La codificación..., p. 153; también en p. 169. I/IV-1848, disp. 163, pp. 206-305 [CP 1848], art. 20.

${ }^{125}$ SÁNCHEZ GONZÁLEZ, La codificación..., p. 165; véase también p. 167.

${ }^{126}$ SÁNCHEZ GONZÁLEZ, La codificación..., p. 173.

${ }^{127}$ SÁNCHEZ GONZÁLEZ, La codificación..., pp. 155, 160, 163, 170.

128 SÁNCHEZ GONZÁLEZ, La codificación..., p. 170

${ }^{129}$ SÁNCHEZ GONZÁLEZ, La codificación..., p. 189.

${ }^{130}$ GARCÍA GOYENA y AGUIRRE, Febrero..., t. II, p. 248.

${ }^{131}$ Cfr. nota 166 .

${ }^{132}$ GARCÍA GOYENA y AGUIRRE, Febrero..., t. II, p. 248.
}

124 «Real decreto, mandando que el Código penal y la ley provisional que dicta las reglas oportunas para la aplicacion de sus disposiciones, se observen como ley en la Península é Islas adyacentes desde el dia $1^{\circ}$ de Julio del corriente año», de 19 de marzo de 1848, en Coleccion Legislativa de España [CLE], $\mathrm{n}^{\circ}$ 43, 
descartado ya el incapaz de 1822; subsiste ubicado el abuso entre las «Estafas y engaños», sin ser propiamente supuesto de estafa stricto sensu, requirente esta de un engaño que cualificaría, transformándolos, unos clásicos delitos de mera usura que en puridad solo lo admiten de cara al exterior (cuando se trate de paliar o encubrir la auténtica naturaleza de la operación: «bien aparezca el préstamo claramente, bien se haya encubierto bajo otra forma» - prevé el artículo-): un arresto de uno a seis meses con su multa es lo que aguarda al infractor ${ }^{133}$. A este precepto, con precedentes - según lo visto- en el Código de 1822 y en el Proyecto Sainz de Andino, le encuentra Pacheco concordancias de Derecho comparado en los equivalentes francés, napolitano (en ambos, abuso de las necesidades, debilidades o pasiones del menor ${ }^{134}$ y austriaco de 1803 (este, mucho menos coincidente, ni siquiera en el sujeto pasivo, más holgado, por pensar en medios supersticiosos o alguna fascinación fraudulenta con abuso de la debilidad del espíritu de otro, tal como el comisionado Clarós predicaba del Código brasileño en sus razonamientos) ${ }^{135}$. El profesor Alvarado Planas confirma en líneas generales la regulación de la materia de este capítulo a partir de una mejorada sistematización sobre la base de los Códigos francés y napolitano ${ }^{136}$; Landrove pone todo el énfasis en el peso del primero y sus derivaciones o área de influencia ${ }^{137}$. Tan solo a guisa de llamada de atención, la casi completa renuncia legislativa a penalizar la codicia de logreros opresores o contumaces arriba al ordenamiento hispano precisamente justo cuando Proudhon y los de su escuela están ya aplicándose a hostigar el edificio del liberalismo rampante, entre otras censuras, con su ataque a todo interés del capital: «queremos la propiedad sin la usura, [...] propiedad sin usura y sin

\footnotetext{
${ }^{133}$ CP 1848, art. 447: «El que abusando de la impericia ó pasiones de un menor le hiciere otorgar en su perjuicio alguna obligacion, descargo ó transmision de derecho por razon de préstamo de dinero, créditos ú otra cosa mueble, bien aparezca el préstamo claramente, bien se haya encubierto bajo otra forma, será castigado con las penas de arresto mayor y multa del 10 al 50 por 100 del valor de la obligacion que hubiere otorgado el menor».

${ }^{134}$ PACHECO, J. F., El Código Penal concordado y comentado, ed. A. Téllez Aguilera (Madrid, 2000), p. 1270: «El que abusare de las necesidades, debilidades o pasiones de un menor, para hacerle suscribir en su perjuicio alguna obligación, carta de pago o descargo, o algun préstamo de dinero, bienes muebles, efectos de comercio o cualquiera otro documento obligatorio, sea cual fuere la forma en que se haga o con que se disfrace la negociación, será castigado con las penas de prisión de dos meses a dos años, y multa, que no podrá exceder de la cuarta parte de las restituciones y perjuicios que se deban a la persona ofendida, ni bajar de veinte y cinco francos. Además podrá aplicársele lo dispuesto en el segundo párrafo del artículo anterior», esto es una interdicción de derechos (Código francés); ibidem, p. 1271: «Es cualificado el fraude por el medio y por la persona: ... 3. ${ }^{\circ}$ Cuando se cometiere abusando de las necesidades, debilidad o pasiones de un menor, para hacerle suscribir en su perjuicio alguna obligación, carta de pago o descargo, o algún préstamo de dinero, cosas muebles, efectos de comercio o cualquiera otro documento obligatorio, sea cual fuere la forma en que se haga o con que se disfrace la obligación» (Código napolitano).

${ }^{135}$ PACHECO, El Código..., p. 1271: «Se hace reo de un delito teniendo en cuenta el valor fijado en el artículo precedente: ... 2..$^{\circ}$ El que valiéndose de medios supersticiosos o de alguna fascinación fraudulenta, abusare de la debilidad del espíritu de otro para causarle perjuicio al mismo o a un tercero». Atiéndase a ACGCP, a. 29, ses. 3-VI-1845, p. 827.

136 ALVARADO PLANAS, J., «Influencias brasileñas, francesas, italianas y austriacas en el Código Penal español de 1848», en VV. AA. (ed. A. Masferrer), La codificación penal española. Tradición e influencias extranjeras: su contribución al proceso codificador (parte general) (Cizur Menor, 2017), p. 146.

${ }^{137}$ LANDROVE DÍAZ, El delito..., pp. 54-65.
} 
abusos» $^{138}$; luego, Marx —por no pasar en este punto de los más sobresalientes nombres- avanzará en la misma dirección ${ }^{139}$.

Pasemos a la otra subcategoría conexa con la especulación usuraria. El Código de 1848 sistematiza como «Delitos contra la propiedad» los «De las casas de préstamos sobre prendas», aquellos que Landrove denomina tipos periféricos de la usura ${ }^{140}$ : uno de ellos apercibe multa contra la dedicación habitual, pero sin licencia de la autoridad, a préstamos sobre seguridades ${ }^{141}$, siguiendo en esto al Código francés; otro, multa más cuantiosa y comiso de lo prestado para quienes en tal ejercicio, matriculados o no ante la autoridad, descuiden llevar libros en regla con las debidas especificaciones identificatorias ${ }^{142}$; por fin, se depara multa porcentual y comiso al prestamista que deje de entregar resguardo ${ }^{143}$. Aporta Pacheco (1808-1865) como concordancias de este capítulo sendos artículos de los Códigos francés de 1810 («modelo de todos los del día») y napolitano de 1819 (reglas de uno de los «[...] pueblos que se parecen a nosotros $\gg)^{144}$, para hacernos evidente que el primero sobre todo ha marcado en buena medida la pauta de la solución hispana: impone multa y prisión a quienes —casi en los mismos términos expresivos en que se hará aquí en 1848 - tengan abiertas casas de préstamo sobre prendas sin autorización o sin el registro reglamentario sobre su actividad $^{145}$; si acudimos al Código de 1791, comprobaremos que no contenía disposición similar ${ }^{146}$, sino que aparece en $1810^{147}$. En cuanto al Código del reino de las Dos Sicilias, ofrece al juzgador, con la multa, alternativa entre prisión y confinamiento a la hora de actuar contra el prestamista que, básicamente, perpetre los mismos actos que en el texto francés, solo que descritos con mayor generalidad y ahorro de pormenores ${ }^{148}$. Groizard recalca el ascendiente galo en concreto sobre el tipo que condena la falta de

138 Véase en PROUDHON, P.-J., La pornocracia o la mujer en nuestros tiempos, trad. A. Peratoner (Madrid, 1995), p. 17

${ }^{139}$ MARX, C., El capital: crítica de la economía política, trad. W. Roces (Méjico, 1973), v. III, pp. 569572.

${ }^{140}$ LANDROVE DÍAZ, El delito..., p. 30.

141 CP 1848, art. 453: «El que sin licencia de la Autoridad se dedicare habitualmente á prestar sobre prendas ú otras seguridades, será castigado con la multa de 20 á 200 duros».

${ }^{142}$ CP 1848, art. 454: «Será castigado con la multa de 100 á 1000 duros el que hallándose dedicado con licencia o sin ella á la industria de que se habla en el artículo anterior, no llevare libros con la debida formalidad, asentando en ellos sin claros ni entrerenglonados las cantidades prestadas, los plazos ó intereses, los nombres y domicilio de los que las reciban, la naturaleza, calidad y valor de los objetos dados en prenda y las demás circunstancias que exijan los reglamentos. / Las cantidades prestadas caerán en comiso».

143 CP 1848, art. 455: «El prestamista que no diere resguardo de la prenda ó seguridad recibida, será castigado con una multa del duplo al quíntuplo de su valor, y la cantidad que hubiere prestado caerá en comiso».

${ }^{144}$ PACHECO, El Código..., pp. 90.

145 PACHECO, El Código..., p. 1280: «Los que sin autorización legal establecieren o tuvieren casas de préstamo sobre prendas, o los que teniendo autorización no llevaren un registro conforme a los reglamentos, en que seguidamente y sin blancos ni entrerenglonados [sic] asienten los objetos prestados, los nombres, profesión y domicilio de los que los reciban, y la naturaleza, calidad y valor de las cosas dadas en prenda, serán castigados con las penas de prisión de quince días a tres meses y multa de ciento a dos mil francos».

146 «Código penal francés de 1791», Revista de Derecho Penal y Criminología, n 1, 2009, trad. J. L. Guzmán Dalbora, pp. 481-517.

${ }^{147}$ Código penal francés, traducido..., p. 88 (art. 411).

148 PACHECO, El Código..., p. 1280: «Los que sin autorización legítima establecieren o tuvieren casas de préstamo sobre prendas, o los que teniendo autorización no llevaren un registro conforme a lo prevenido en los reglamentos, serán castigados con las penas de prisión o confinamiento de primer grado y multa correccional». 
licencia ${ }^{149}$. El profesor Masferrer Domingo confirma la influencia de ambos Códigos y añade la del brasileño de 1830 , verosímil canal de transmisión desde el origen franco ${ }^{150}$.

Como diferencias más notorias entre tales precedentes y la derivación española, en primer lugar, esta introduce en el tipo una habitualidad cuya concurrencia no requieren expresamente aquellos otros Códigos para su reproche penal —distinción informante ya de las Partidas al perseguir la usura material ${ }^{151}$, mas sin duda su compartida opción referente a establecer o tener casas de préstamo sobre prendas comporta un establecimiento que entonces solo puede ser habitual, con lo cual vendría a neutralizarse la desemejanza; en segundo término, al punto se echa de ver que, si tales influjos se manifiestan notorios en la definición de conductas, dejan de serlo cuando se pasa a su punición, más severa en Francia y Nápoles — se compromete la libertad-, mientras que en España queda circunscrita a la omnipresente multa y a un comiso de las cantidades prestadas que a Pacheco incluso se le antoja medida «[...] demasiado dura para que se ejecute» por cuanto que «[...] excedería quizá de toda justa proporción» ${ }^{152}$. Las coincidencias, aparte de la similar redacción, pasan por la despenalización de la usura en sí misma, no un retorno al sistema de libertad absoluta en el pacto de intereses, sino tan solo la irrelevancia para los efectos penales de cualquier exceso en ellos, quedando por descontado expedita la nulidad o reducción al interés legal de acuerdo con la legislación civil ${ }^{153}$. Se castiga, pues, únicamente el negocio de las casas de préstamo sin autorización gubernativa o con inobservancia de las formalidades reglamentarias prescritas acerca de libros de registro y resguardos, mas no la práctica usuraria stricto sensu. Dado que, con su señalamiento del control correspondiente al Estado y de las obligaciones de los particulares prestamistas, estos tres preceptos que conforman el capítulo llegan a constituir lo que Pacheco llama reglamento de las casas de préstamo («desde luego no tenemos otro»), sí que indirectamente - aquilata el jurista ecijano«tal intervención [...] es una buena regla de policía para evitar desórdenes y usuras, y no otra cosa ${ }^{154}$, pero sin ir ni llevar más allá el empeño del Estado, puesto - concluye- «[...] que no creemos sea prudente y oportuno el que la ley penal descargue sus rigores sobre tal acción, aunque sea mala y reprobada», y ello por un mero cálculo utilitario de no propiciar que las usuras se acrecienten por reacción frente a los adicionales riesgos dimanantes de su persecución en vía criminal ${ }^{155}$, confiando a los tribunales civiles la pertinente rebaja, a la vista del movedizo valor del dinero, de cualquier estipulación de intereses desmesurados, al menos — de acuerdo con lo ya anticipado- hasta la ley de 1856.

La revisión de 1850 deja intactos en el Código tanto el abuso de la impericia o pasiones de un menor como los preceptos sobre casas de préstamos del texto legal dos años anterior ${ }^{156}$. Lo mismo ocurre en 1870 con el primer supuesto ${ }^{157}$ (durante el

\footnotetext{
${ }^{149}$ GROIZARD Y GÓMEZ DE LA SERNA, El Código..., t. VII, p. 401.

${ }^{150}$ MASFERRER DOMINGO, A., Tradición y reformismo en la Codificación penal española: hacia el ocaso de un mito. Materiales, apuntes y reflexiones para un nuevo enfoque metodológico $e$ historiográfico del movimiento penal europeo (Jaén, 2003), p. 230.

${ }^{151}$ P, V.11.40.

152 PACHECO, El Código..., p. 1281.

${ }^{153}$ V. gr., PACHECO, El Código..., pp. 1282-1283; GARCÍA GOYENA y AGUIRRE, Febrero..., t. II, p. 248.

${ }^{154}$ PACHECO, El Código..., p. 1281.

155 PACHECO, El Código..., p. 1283.

${ }^{156}$ Código Penal reformado de 30 de junio de 1850, arts. 458, 464 a 466.
} 
recorrido positivo de este corpus, con éxito de la codificación civil en 1889, adviene una reducción, desde los veinticinco años, de la mayoría de edad, que queda establecida en veintitrés ${ }^{158}$ ), no así con los de la otra especie, los atinentes a formalidades, entre los que se suprime una de las tres cláusulas del capítulo y con ella la sanción en vía penal de la falta de licencia reglamentaria para el negocio en cuestión («[...] en contradicción con los derechos que la Constitución vigente reconoce á los españoles para ejercer libremente toda clase de profesiones e industrias» ${ }^{159}$-elucida Groizard-); se prescinde del comiso de las cantidades prestadas por los tratantes incursos en las inobservancias formales que aquí se reprimen; y ya lo demás son variaciones sin mayor relieve en la redacción, como cuando la multa reservada al prestamista reprensible se lleva de duros a pesetas, pero sin modificar la cantidad ${ }^{160}$.

Como único rastro del paso de estas cuestiones por manos del legislador, al discutirse en las Cortes la autorización al gobierno para plantear como ley provisional el proyecto de 1869, Francisco Silvela, forjador de aquel célebre apelativo de Código de verano para el corpus reformado, se refiere a algunos casos que halla en él pertenecientes a un sistema en que «la pena indudablemente tiene un carácter preventivo», en cuanto puede recaer sobre un inculpado por omisiones o negligencias distantes de la consumación - como el escamoteo de libros y resguardos- lo cual recela que «[...] no sea lógico con las doctrinas individualistas»:

El mismo principio me ha llamado la atencion [...] en lo relativo, por ejemplo, á las casas de préstamos, en las cuales se establece una intervencion particular, y se exige que al que vaya á tomar dinero prestado se le den determinadas garantías, entendiendo el Estado que el que toma dinero no tiene medios suficientes para conocer las garantías que le son convenientes $[\ldots]^{161}$.

El recelo liberal ante todo intervencionismo del Estado inspira tales prevenciones contra unas cláusulas que, presentes en el ordenamiento penal solo desde hacía un par de decenios, aún chirrían pese a su generalización comparada, sin verse, por otro lado, nunca libres del achaque de vulnerar la máxima de que este sector debe actuar siempre como el último recurso de la política social.

Groizard ahonda señalando concordancias del artículo de abuso sobre menor, «[...] una figura de delito, trazada con rasgos parecidos en casi todos los Códigos modernos», en los más notables de Europa (Francia, Bélgica, Alemania, Portugal, Italia e incluso el cantón suizo de Tesino o Hungría) y la mayor parte de los de las repúblicas americanas (Méjico, Chile, Perú, Paraguay, Guatemala, Uruguay, Argentina, Colombia,

\footnotetext{
157 «Ley, autorizando al Ministro de Gracia y Justicia para plantear como provisional el adjunto proyecto de reforma del Código penal», de 18 de junio de 1870, en CLE, n 103, I/VI-1870, disp. 370, pp. 9051032 [CP 1870], art. 553.

158 «Real decreto, mandando insertar en la Gaceta el texto de la nueva edición del Código civil, con las enmiendas y adiciones propuestas por la Sección de lo civil de la Comisión de Codificación», de 24 de julio de 1889, en $C L E$, no 143 , VII-XII-1889, disp. 62, pp. 138-466, art. 320.

${ }^{159}$ GROIZARD Y GÓMEZ DE LA SERNA, El Código..., t. VII, p. 401.

${ }^{160}$ CP 1870, art. 559: «Será castigado con la multa de 500 á 5000 pesetas el que hallándose dedicado á la industria de préstamos sobre prendas, sueldos ó salarios, no llevare libros asentando en ellos sin claros ni entrerenglonados las cantidades prestadas, los plazos ó intereses, los nombres y domicilios de los que las reciban, la naturaleza, calidad y valor de los objetos dados en prenda, y las demás circunstancias que exigen los reglamentos»; art. 560: «El prestamista que no diere resguardo de la prenda ó seguridad recibida, será castigado con una multa del duplo al quíntuplo de su valor».

${ }^{161}$ Diario de Sesiones de las Cortes Constituyentes (Madrid, 1870), ses. 307 (15-VI-1870), p. 8887.
} 
Brasil) ${ }^{162}$. Más allá, «las ideas económicas han entrado de medio siglo á esta parte en el texto de las leyes, y todavía más en las costumbres de nuestro foro», siendo así que «la usura [...] ha sido borrada en nuestros días del catálogo de los delitos en casi todas las naciones ${ }^{163}$, restringiéndose la incriminación a esos tipos periféricos de las casas dedicadas al tráfico pignoraticio que «como la ausencia de las respectivas concordancias lo da a entender, hay países donde no se han incriminado esta clase de hechos. En otros, [...] se han castigado solamente como contravenciones ó faltas», de modo que Groizard ahora solo puede consignar concordantes preceptos en los articulados francés, alemán, portugués y de algunas de las que al alborear el siglo eran todavía colonias indianas (Perú, Paraguay, Guatemala) ${ }^{164}$.

Aunque el Proyecto de Código Civil de 1836 remitía el maximum del interés a una futura ley especial y el de 1851 perseveraba en un coto puesto en el doble del interés legal ${ }^{165}$, la abolición de la tasa se impone por la ya aludida ley de $1856^{166}$, en la línea individualista liberal marcada por la Revolución francesa ${ }^{167}$, para prevalecer el resto de la centuria e incluso entrar en la siguiente hasta que, sin recuperar ningún tope, se deje el control en manos del arbitrio judicial: los Códigos de Comercio en 1885 y Civil en 1889 seguirían por esa misma senda abierta a la libertad de pacto ${ }^{168}$ que hará lamentar al magistrado Covián, prolijo en la consignación de excesos y fraudes sin cuento de que se dice testigo o conocedor, hasta qué punto

Abandonando nuestra manía constante de imitación á Francia, hemos prescindido también de lo tradicional, la teoría de las Recopilaciones, de suerte que cuando la elaboración de los primeros Códigos penales no se creyó oportuno que la ley descargara sus rigores sobre tales acciones, aunque sean malas y reprobadas [...]

Todo se sacrificó á que prevalecieran en España las teorías de Turgot, Montesquieu, Bastiat y otros economistas y jurisconsultos, cuando precisamente en su patria no habían conseguido sacar adelante el principio de la libertad ${ }^{169}$.

Sin embargo, al ampliar el visor, se observa que «a partir de 1830, la mayor parte de las leyes restrictivas o de tasa, fueron derogadas. Así lo hicieron Inglaterra, Austria, España, Italia, Holanda, Bélgica, Suecia, Noruega y la mayor parte de los Cantones Suizos. El ejemplo fué seguido más tarde por Alemania y por varios Estados de América del Norte» ${ }^{170}$. El retorno se aprecia generalizado a la alternativa que imperara durante la lejana Antigüedad en el orbe romano.

\section{NUEVA REPRESIÓN DE LA USURA EN EL SIGLO XX}

\footnotetext{
162 GROIZARD Y GÓMEZ DE LA SERNA, El Código..., t. VII, pp. 285-290.

${ }^{163}$ GROIZARD Y GÓMEZ DE LA SERNA, El Código..., t. VII, pp. 291-292.

${ }^{164}$ GROIZARD Y GÓMEZ DE LA SERNA, El Código..., t. VII, pp. 398-402.

165 «Proyecto de Código civil de 1836», apud LASSO GAITE, J. F., Crónica de la Codificación española. 4. Codificación civil (génesis e historia del Código) (Madrid, 1970), v. II, apd. III, pp. 89-320, art. 1337; «Proyecto de Código civil de 1851», ibidem, apd. IV, pp. 321-496, art. 1650.

166 «Ley, aboliendo la tasa sobre el interés del capital en los préstamos á numerario», de 14 de marzo de 1856, en CLE, $\mathrm{n}^{\mathrm{o}}$ 67, I/III-1856, disp. 218, pp. 357-358, art. $1^{\circ}$.

${ }^{167}$ BURGOS CRUZADO, «La usura...», p. 318.

168 «Real decreto, disponiendo que el Código de Comercio se observe como ley en la Península é Islas adyacentes desde el $1^{\circ}$ de Enero de 1886; y más que se determina», de 22 de agosto de 1885 , en $C L E, \mathrm{n}^{\circ}$ 135, VII/XII-1985, disp. 384, pp. 473-668, art. 315. CC 1889, arts. 1740, 1753 a 1757.

${ }^{169}$ COVIÁN, «Usura», pp. 641-642.

${ }^{170}$ VALLÉS Y PUJALS, J., Del préstamo a interés, de la usura y de la hipoteca (Barcelona, 1933), p. 91.
} 
La crisis económica finisecular propicia una exacerbación del recurso al préstamo de proporciones usurarias, hasta un punto tal que precisa ser atajado en principio mediante el arma civil de la anulación a discernimiento de los tribunales ${ }^{171}$. Con copioso muestrario internacional de leyes citadas en la discusión parlamentaria ${ }^{172}$, la ley de 23 de julio de 1908, referente á la nulidad de ciertos contratos de préstamo y más conocida como de represión de la usura o ley Azcárate contra la usura (por el ministro que la autoriza con su firma, Gumersindo de Azcárate), solo se extiende a la ordenación jurídico-privada y a la corrección disciplinaria al prestamista habitual, sin detrimento en su caso de la responsabilidad criminal, mediante multa ${ }^{173}$ del juzgado de primera instancia que declare la nulidad - pero Covián no lo ha contemplado ni en un solo caso $^{174}$ - tras sorprender a su prudente arbitrio ${ }^{175}$ «[...] un interés notablemente superior al normal del dinero y manifiestamente desproporcionado con las circunstancias del caso ó en condiciones tales que resulte [...] leonino, habiendo motivos para estimar que ha sido aceptado por el prestatario á causa de su situacion angustiosa, de su inexperiencia ó de lo limitado de sus facultades mentales» ${ }^{176}$ : a decir del fiscal Rodríguez Martín, dicha corrección disciplinaria no entraña sino una «[...] acción francamente punitiva, pues por la cuantía de las multas [...] se trata de verdaderas penas de carácter aflictivo y correccional, según la clasificación [...] del Código» ${ }^{177}$. El reglamento dado un año después para las casas de préstamo acaba por fijar el contenido de la llevanza de libros y extensión de resguardos de parte de los prestamistas $^{178}$. Algo más tarde, ya 1910, y en orden a aquilatar la habitualidad punible, otro real decreto pone en marcha el registro central de contratos de préstamos declarados nulos ${ }^{179}$. Todavía, cierta real orden de 1924 sobre establecimientos de compraventa, impuesto el gobierno en los reacomodos ideados por el voraz espíritu de lucro, expande su protección sobre el menesteroso «[...] que antes pignoraba $o$ enajenaba con pacto de retro» a la vista de «[...] que las operaciones que en otro tiempo hacían las casas de préstamos han tomado el carácter de contratos de compraventa mercantil», tendiendo al paso una conexión entre los prenderos y los receptadores ${ }^{180} \ldots$

\footnotetext{
${ }^{171}$ LANDROVE DÍAZ, El delito..., p. 33.

172 COVIÁN, «Usura», pp. 645-646.

173 «Ley referente á la nulidad de ciertos contratos de préstamo», de 23 de julio de 1908 , en Colección Legislativa de España. Primera Serie. Parte Primera. Legislación y Disposiciones de la Administración Central [CLEAC], no 32.2, IV/VII-1908, disp. 274, pp. 738-740, arts. 5, 11 y 14. Amplíese en COVIÁN, «Usura», pp. 645-660; RODRÍGUEZ MARTÍN, A., Represión de la usura: comentarios y jurisprudencia a la Ley de 23 de julio de 1908 y al reglamento vigente de las casas de préstamos y establecimientos similares (Madrid, 1923), pp. 123-125, 162-163; VALLÉS Y PUJALS, Del préstamo..., pp. 127-128; VIZCARRO, El préstamo..., pp. 139-144; GARCÍA ARÁN, M., «Sentido actual y contenido material de la incriminación de la usura», Revista de la Facultad de Derecho de la Universidad Complutense, $\mathrm{n}^{\circ}$ 6, 1983, pp. 286-298; o JIMÉNEZ MUÑOZ, F. J., La usura: evolución histórica y patología de los intereses (Madrid, 2010), pp. 115-116.

${ }^{174}$ COVIÁN, «Usura», p. 659. Concorde, VIZCARRO, El préstamo..., p. 145.

175 COVIÁN, «Usura», p. 656-657; RODRÍGUEZ MARTÍN, Represión..., pp. 91-100; VALLÉS Y PUJALS, Del préstamo..., pp. 116-122; VIZCARRO, El préstamo..., pp. 103-118.

${ }^{176}$ Ley de 23-VII-1908 cit., art. $1^{\circ}$. Atiéndase a VIZCARRO, El préstamo..., pp. 37-70.

${ }^{177}$ RODRÍGUEZ MARTÍN, Represión..., p. 124.

178 «Real decreto aprobando el reglamento de las Casas de Préstamos y Establecimientos similares», de 12 de junio de 1909, en CLEAC 35.2, IV/VII-1909, disp. 185, pp. 553-565, arts. 8, 20, 21, 50.5, 50.14 y 54.

179 «Real decreto disponiendo cómo ha de formarse el Registro central de contratos de préstamos declarados nulos», de 27 de febrero de 1910, en CLEAC, no 37.1, I/V-1910, disp. 118, pp. 337-340.

180 «Real orden disponiendo se observen las prescripciones, que se publican, por todos los establecimientos o industriales que se dediquen a la compra y venta de objetos de oro, plata o platino, con
} 
La ley de 1908 «preparó el camino a la exigencia de responsabilidad penal [...], restableciendo el principio de la Novísima Recopilación, que castigaba entre los delitos las usuras» ${ }^{181}$ - leemos a los continuadores de la obra de Martínez Alcubilla-. Así, pues, el Proyecto de Código Penal pergeñado en 1927 se relaciona, partiendo de ellos, con los principios inspiradores de la Ley Azcárate: «era necesario reforzar con estos preceptos los escasos que el Código actual contiene, y estima la Comisión que serán suficientes los consignados para hacer más eficaz la citada Ley de 1908 y sancionar actos frecuentes de simulación y disfraz de escandalosas operaciones usurarias» ${ }^{182}$ —declara intenciones el preámbulo-, «[...] á las cuales llamó la ley de Partida [...] "provisiones hechas en manera de usura"», según filia el Alcubilla ${ }^{183}$. El Proyecto se dilataba en una ofensiva contra la usura algo mayor de la que quedará luego en el Código resultante: abuso de necesidad, ligereza o inexperiencia de una persona, usura encubierta, sucesiva, abuso de menor, las irregularidades administrativas de casas de préstamos y la usura reiterada ${ }^{184}$, modalidad que, cuando no concurran otras circunstancias calificativas, acaba por dejarse a la virtualidad constrictora de la corrección disciplinaria civil aprontada en 1908.

Culminación del viraje legislativo en revisión de las tesis amorales del libre comercio, en 1928, el novedoso capítulo «De la usura» no abandona los «Delitos contra la propiedad», donde incorpora no las previsiones de la Ley de 1908 —según apunta San Martín Losada ${ }^{185}$-, pero sí su espíritu. Con acometida demasiado casuista $^{186}$, el artículo inicial abarca tres transgresiones aparejándoles reclusión de hasta seis meses y multa: el aprovechamiento de la necesidad, ligereza o inexperiencia de una persona — de toda edad, amplitud que Covián halla anticipada en el Código belga de $1867^{187}$ para hacerle aceptar un contrato bilateral, «sea cualquiera el nombre que se dé por las partes», con ventajas pecuniarias tales que «[...] el lucro obtenido resultare en notable desproporción con el servicio prestado»; la obtención, apoyado en las mismas circunstancias, de intereses notablemente excesivos por medio de contrato disfrazado; y la adquisición o enajenación de los créditos indicados con conocimiento de sus particularidades, es decir la usura sucesiva ${ }^{188}$. La segunda disposición actualiza el

o sin piedras preciosas, relojes, ropas, muebles y objetos usados o de ocasión», de 19 de enero de 1924, en CLEAC, $\mathrm{n}^{\circ}$ 83.1, I/II-1924, disp. 90, pp. 225-227.

${ }^{181}$ Notas a Código Penal de 8 de Septiembre de 1928 (Madrid, 1928), p. 152.

182 «Primera parte, no impresa, del apéndice en que se publicó el Proyecto de Código Penal, remitido a la Asamblea por el Sr. Ministro de Gracia y Justicia», en Asamblea Nacional. Diario de Sesiones [ANDS], $\mathrm{n}^{\mathrm{o}} 3$, 23-XI-1927, apd. $1^{\mathrm{o}}$-a, p. 31.

${ }^{183}$ Notas a Código... de 1928, p. 152. Véase $P$, V.11.31 y 40.

184 «Proyecto de Código Penal, remitido por el señor Ministro de Gracia y Justicia», en $A N D S, \mathrm{n}^{\mathrm{o}} 3,23-$ XI-1927, apd. $1^{\circ}$-b, arts. 937 a 943.

185 SAN MARTÍN LOSADA, L., El Código Penal de 1928: su estudio y comparación con el de 1870 (Madrid, 1928), p. 195.

${ }^{186}$ QUINTANO RIPOLLÉS, A., Comentarios al Código Penal (Madrid, 1966), p. 1028.

${ }^{187}$ COVIÁN, «Usura», p. 641.

188 «Real decreto-ley aprobando el proyecto de Código penal, que se inserta; y disponiendo que empiece a regir como ley del Reino el día $1^{\circ}$ de Enero de 1929», de 8 de septiembre de 1928, en CLEAC, $\mathrm{n}^{\circ} 111.5$, IX/X-1928, disp. 12, pp. 21-303 [CP 1928], art. 739: «Será castigado con la pena de dos meses y un día a seis meses de reclusión y multa de 1000 a 5000 pesetas: $1^{\circ}$. El que aprovechándose de la necesidad, de la ligereza o de la inexperiencia de una persona, le concediere dinero a préstamo, o consintiere en prorrogar el término para el pago de un crédito, o en relación a cualquier otro contrato bilateral destinado a satisfacer las mismas necesidades económicas, sea cualquiera el nombre que se dé por las partes, se hiciere prometer o aceptare por sí mismo o para otros ventajas pecuniarias, efecto de las que, y según las circunstancias, el lucro obtenido resultare en notable desproporción con el servicio prestado. $/ 2^{\circ}$. El que 
supuesto de abuso de impericia o pasiones de un menor, al que se agrega más abajo, en el curso de la redacción, el incapacitado, incorporando, tras ello, una presunción de abuso siempre que el contrato se celebre sin intervención de su representante legal y, luego, la recusación como posible excusa de la falsa atribución por el menor de bienes, derechos o condiciones determinantes de su capacidad o responsabilidad ${ }^{189}$, lo que habrá que interpretar a la luz de la Ley de 23 de julio de 1908: «[...] á menos que pruebe haber tenido motivos racionales y suficientes para creer que era mayor de edad» ${ }^{190}$, como la aportación — prevista en el Proyecto, eliminada en el Código- de «[...] documentos que a ser auténticos harían prueba legal»; la pena reclusiva puede llegar hasta los dos años y la multa hasta la mitad del valor de la obligación. Los otros dos preceptos restantes rehacen las heredadas formulaciones típicas de la carencia de libros en regla ${ }^{191}$ y del desenvolvimiento de esta actividad sin resguardos, pero añadiendo a las multas en este último supuesto una agravación privativa de la libertad de hasta medio año cuando se dejase de consignar la transformación de la prenda ${ }^{192}$.

Siguiendo la rehechura de esta materia ensayada por la Comisión General de Codificación en el Código dispuesto para el protectorado marroquí en $1914^{193}$, el corpus penal de 1932 opta por una denominación del capítulo integradora: «De la usura y de las casas de préstamos sobre prendas» y corrige con presidio y multa la usura habitual ${ }^{194}$, la encubierta $^{195}$ y el abuso de menor ${ }^{196}$, solo con multa las consabidas irregularidades

aprovechando las circunstancias mencionadas en el párrafo anterior, por medio de letras de cambio, ventas con pacto de retroventa, o empleando cualquiera otro medio disfrazado para asegurar el cobro, obtuviere intereses notablemente excesivos. $/ 3^{\circ}$. El que con conocimiento del negocio adquiriere un crédito de la especie mencionada en el párrafo anterior, o lo enajenare, o reclamare por cualquier concepto intereses notoriamente desproporcionados al servicio prestado».

${ }^{189}$ CP 1928, art. 740: «El que abusando de la impericia o pasiones de un menor le hiciere otorgar en su perjuicio alguna obligación, descargo o transmisión de derechos por razón de préstamo de dinero, crédito u otra cosa mueble, bien aparezca el préstamo claramente, bien se halle encubierto bajo otra forma, será castigado con las penas de dos meses y un día a dos años de reclusión y multa del 10 al 50 por 100 del valor de la obligación que hubiere otorgado el menor, sin que sea nunca menor de 1000 pesetas. / Se presumirá que hay abuso de la inexperiencia del menor o incapacitado siempre que el contrato se celebre sin la intervención del padre, de la madre o del tutor. / No eximirá de ninguna de las responsabilidades expresadas el hecho de que el menor se atribuyere falsamente bienes, derechos o condiciones de edad o de otra clase que puedan influir en su capacidad o responsabilidad».

${ }^{190}$ Ley de 23-VII-1908, art. 10.

${ }^{191}$ CP 1928, art. 741: «Será castigado con la multa de 1000 a 5000 pesetas, el que hallándose dedicado a la industria de préstamos sobre prendas, sueldos o salarios o las similares de compraventa mercantil o cualquier otro nombre que pueda dárseles, no tuviere libros o no los llevare con los requisitos exigidos en los Reglamentos».

192 CP 1928, art. 742: «El prestamista o dueño de casa de compraventa mercantil o análoga que no diere resguardo de la prenda o seguridad recibida, será castigado con una multa de 1000 a 10000 pesetas. / Si la prenda fuere alterada o transformada y se omitiera consignar tal circunstancia en el registro, se impondrá al prestamista la pena de dos meses y un día a seis meses de reclusión y multa de 1000 a 10000 pesetas».

193 «Código Penal» de 1 de junio de 1914, en Leyes de Marruecos, eds. E. Mora Regil y C. Rodríguez Aguilera (Madrid, 1947), prt. II, pp. 3-91, arts. 437, 444 y 445.

194 «Ley de 27 de octubre de 1932 promulgando el Código Penal de 1870 reformado según la Ley de Bases de 8 de Septiembre», en CLEAC, n 131.4, IX/X-1932, disp. 1614, pp. 595-736 [CP 1932], art. 532: «Será castigado con la pena de presidio menor en sus grados medio y mínimo y multa de 5000 a 50000 pesetas, el que habitualmente se dedicare a préstamos usurarios».

195 CP 1932, art. 533: «Será castigado con igual pena el que encubriere con otra forma contractual cualquiera la realidad de un préstamo usurario, aunque no exista habitualidad».

196 CP 1932, art. 534: «Será castigado con la pena de presidio menor en sus grados medio y máximo y multa de 5000 a 50000 pesetas, el que, abusando de la impericia o pasiones de un menor, le hiciere otorgar en su perjuicio alguna obligación, descargo o transmisión de derechos por razón de préstamo de 
formales en la industria de préstamos sobre prendas ${ }^{197}$. Sin ninguna consideración hacia el que llama Código gubernativo con sus innovaciones sobre la base de 1908, su exposición de motivos enfatiza en cuánta medida «el Gobierno de la República tuvo vivo deseo de que este delito encajase en el nuevo Código», patente la insuficiencia o ineficacia de la ley civil y en armonía con «[...] el concepto de propiedad que ahora surge al imperio de la democracia, [...] este nuevo delito responde a la nueva Constitución de la República española» ${ }^{198}$ : con su imperio — de la democracia, de la Constitución - o sin él, puesto que tal escogimiento político-criminal iba a conservarse tal cual articulado, con mínimas alteraciones, a lo largo de la etapa y codificación franquista hasta que el vigente Código, sin perjuicio de su cobertura también democrático-constitucional, se decante por una nueva retirada del ius puniendi de los dominios de la usura.

\section{RECAPITULACIÓN}

La secularización jurídica y, en concreto, el proceso de despenalización de ciertos delitos intensamente traspasados de la idea de pecado en el Derecho histórico, como el de usura, acceden a la ley a lo largo del siglo XIX, pero ya antes, con progresiva fuerza al correr la precedente centuria dieciochesca, el fenómeno había tenido su abono en la doctrina y el usus fori patrios con un sentido expansivo de los casos en que el prestamista podía ver justificado su beneficio o interés, delineándose así, sin subscribir la pauta del continuismo ni dar en ruptura tajante, un curso evolutivo, paulatino, ya en marcha más bien con anterioridad al fenómeno codificador ${ }^{199}$, el cual encontrará ya completado el soporte ideológico para su desenvolvimiento: como lo expresaba el abogado cubano Ramón Francisco Valdés, «esta es ya cuestion juzgada por el siglo ${ }^{200}$. Empero, en tanto que la doctrina dieciochesca española se contentaba con justificar una creciente, aunque calmosa, expansión de motivos -menoscabos, albures - para el interés lícito al prestamista, los más significados reformistas europeos habían levantado ya la bandera del desalojo de la usura de la ley penal: a su estímulo y por esta vía, luego tangible en Derecho comparado, será como se incorpore al sistema patrio el novedoso retraimiento hacia la atipicidad de unos delitos de arraigada recriminación en la política criminológica del Antiguo Régimen.

En 1822, balbuceante la Codificación, pero vigoroso el espíritu secularizador, se dejará conminado, a imagen de ejemplos foráneos, pero asimismo de una tradición localizable ya en las Partidas, el usurario abuso sobre menor. Otros supuestos no propiamente de logrería, pero colindantes con ella - aunque en un nivel que bien hubiera podido quedarse en reglamentario-, cuales son los desarreglos formales en la

\footnotetext{
dinero, crédito u otra cosa mueble, bien aparezca el préstamo claramente, bien se halle encubierto bajo otra forma».

${ }^{197}$ CP 1932, art. 535: «Será castigado con la multa de 500 a 5000 pesetas el que hallándose dedicado a la industria de préstamos sobre prendas, sueldos o salarios, no llevare libros asentando en ellos sin claros ni entrerrenglonados las cantidades prestadas, los plazos o intereses, los nombres y domicilios de los que las reciban, la naturaleza, calidad y valor de los objetos dados en prenda, y las demás circunstancias que exigen los reglamentos»; art. 536: «El prestamista que no diere resguardo de la prenda o seguridad recibida, será castigado con una multa del duplo al quíntuplo de su valor».

198 CP 1932, «Exposición de motivos», p. 617. Testimóniese la insuficiencia civil, en BURGOS CRUZADO, «La usura...», p. 319.

${ }^{199}$ MASFERRER DOMINGO, Tradición ..., pp. 190-191.

${ }^{200}$ VALDÉS, R. F., Diccionario de legislacion y jurisprudencia criminal, en que se comprenden todas las disposiciones que rigen en la isla de Cuba, segun las leyes especiales orgánicas de su administracion de Justicia, y autos acordados vijentes (La Habana, 1859), p. 426.
} 
llevanza de las casas de préstamo, acceden igualmente al Código Penal —desde 1848a semejanza de experiencias extranjeras. Y mucho más adelante —otro siglo ya, el $\mathrm{XX}$-, algo parecido sucederá cuando el legislador vuelva a sentir la necesidad de sujetar la usura a reconvención procediendo en concreto contra las usuras habitual o encubierta, aunque otra vez nos quepa invocar una solera autóctona remontable hasta la obra cimera de Alfonso el Sabio. Los más recientes derroteros del leviatán capitalista parecen haber propiciado el último giro o desvío legislativo hacia la reliberalización a ultranza del sector en beneficio de la audacia bancaria o de la voracidad de empresas de financiación rápida a alto riesgo.

\section{BIBLIOGRAFÍA}

ALVARADO PLANAS, J., «Influencias brasileñas, francesas, italianas y austriacas en el Código Penal español de 1848», en VV. AA. (ed. A. Masferrer), La codificación penal española. Tradición e influencias extranjeras: su contribución al proceso codificador (parte general) (Cizur Menor, 2017).

ÁLVAREZ CORA, E., «Usura y censura del Santo Oficio en el siglo XVIII», en VV. AA. (ed. E. Gacto Fernández), Inquisición y censura: el acoso a la inteligencia en España (Madrid, 2006).

ÁlVAREZ POSADILlA, J., Práctica criminal por principios, ó modo y forma de instruir los procesos criminales de las causas de oficio de justicia (Valladolid, 1802).

ASSO Y DEL RÍO, I. J., y MANUEL Y RODRÍGUEZ, M. de, Instituciones del Derecho civil de Castilla (Madrid, 1805).

BARÓ PAZOS, J., «El derecho penal español en el vacío entre dos códigos (18221848)», AHDE, n 83, 2013.

BASTIAT, F., Armonías económicas, trad. F. Pérez Romero (Madrid, 1858).

BECCARIA, C., Tratado de los delitos y de las penas, trad. J. A. de las Casas (Madrid, 1774).

BECCARIA, C., «Elementi di economía pubblica», Opere (Milano, 1822).

BENTHAM, J., Defensa de la usura, ó cartas sobre los inconvenientes de las leyes que fijan la tasa del interés del dinero, trad. J. E. (París, 1828).

BENTHAM, J., Principios de legislacion y condificacion, extrc. F. Ferrer y Valls (Madrid, 1834).

BERNÍ, J., Practica criminal (Valencia, 1749).

BEXON, S., Application de la théorie de la législation pénale, ou code de la sureté publique et particulière (Paris, 1807).

BLACKSTONE, W., Commentaries of the laws of England, adap. R. M. Kerr (London, 1862), t. II. 
BURGOS CRUZADO, A., «La usura y sus remedios», Revista General de Legislación y Jurisprudencia, $\mathrm{n}^{\circ}$ 160, 1932.

CASABÓ RUIZ, J. R., «Los orígenes de la codificación penal en España: el plan de Código criminal de 1787», Anuario de Derecho Penal y Ciencias Penales, $\mathrm{n}^{\circ} 22.2$, V/VIII-1969.

CLAVERO, B., Usura: del uso económico de la religión en la historia (Madrid, 1984).

COBO DEL ROSAL, G., «Los mecanismos de creación normativa en la España del siglo XIX a través de la codificación penal», Anuario de Historia del Derecho Español [AHDE], $\mathrm{n}^{\mathrm{o}} 81,2011$.

CORNEJO, A., Diccionario histórico, y forense del Derecho real de España (Madrid, 1779).

COVIÁN, V., «Usura», en Enciclopedia jurídica española (Barcelona, 1910).

DEL VALLE LINACERO, F. y CHAVARRÍA Y MONTOYA, A. de, Leyes penales vigentes actualmente en España, recopiladas de nuestros códigos, ordenanzas y colecciones de decretos. Reflexiones sobre los vicios de la administracion de Justicia, abusos de algunos curiales, y necesidad de una pronta y eficaz reforma de nuestros Códigos (Madrid, 1840).

DOU Y DE BASSÓLS, R. L., Instituciones del Derecho público general de España, con noticia del particular de Cataluña y de las principales reglas de gobierno en qualquier estado (Madrid, 1800/1802).

ECHEBARRÍA Y OJEDA, P. A., Los delitos y las penas en el Diccionario de Echebarría de 1791, ed. B. Mapelli Caffarena y A. García Benítez (Sevilla, 2006).

ELIZONDO, F. A., Práctica universal forense de los tribunales de España, y de las Indias (Madrid, 1788).

ESCRICHE, J., Diccionario razonado de legislacion y jurisprudencia (Madrid, $1838 / 1845)$.

FAIGUET DE VILLENEUVE, J., «Usure», en D. Diderot y J. le Rond d'Alembert (eds.), Encyclopedie, ou dictionnaire raisonné des sciences, des arts et des métiers, par une société de gens de lettres (Paris, 1751-1772).

FEBRERO, J., Librería de escribanos, é instruccion jurídica teorico práctica de principiantes (Madrid, 1769/1781), Parte $1^{\mathrm{a}}$.

FILANGIERI, C., Ciencia de la legislacion, trad. J. Ribera (Madrid, 1821/1822).

GARCÍA GOYENA, F., Código criminal español segun las leyes y práctica vigentes comentado y comparado con el Penal de 1822, el francés y el inglés (Madrid, 1843), t. 
I, p. 360. Corrobora tales noticias Pío Laborda en su edición anotada del Código civil francés, ed.-trad. P. Laborda y Galindo (Madrid, 1850).

GARCÍA GOYENA, F., y AGUIRRE, J., Febrero ó Librería de jueces, abogados y escribanos (Madrid, 1852).

GÓMEZ DE LA SERNA, P., y MONTALBÁN, J. M., Elementos de Derecho civil y penal de España, precedidos de una reseña histórica de la legislacion española (Madrid, 1843).

GÓMEZ RIVERO, M. C., «La usura: cuarenta y tantos años después», en VV. AA. (dirs. F. Muñoz Conde et al., ed.-coord. M. A. Núñez Paz), Un Derecho penal comprometido: Libro Homenaje al Prof. Dr. Gerardo Landrove Díaz (Valencia, 2011).

GRAVEN, J., «Montesquieu y el Derecho penal», trad. M. A. Moncada, Revista CENIPEC, $\mathrm{n}^{\circ} 2.25,2006$.

GROIZARD Y GÓMEZ DE LA SERNA, A., El Código Penal de 1870 concordado y comentado (Burgos/Salamanca, 1870/1899).

GUTIÉRREZ, J. M., Práctica criminal de España (Madrid, 1804/1806).

HERNÁNDEZ DE LA RÚA, V., Lecciones de Derecho español (Madrid, 1838), t. II.

JIMÉNEZ MUÑOZ, F. J., «El tratamiento de los intereses en el Derecho canónico y en el Derecho islámico», Revista de Derecho UNED, n 3, 2008.

KERR, R. M., «Additions» a Blackstone, Commentaries..., t. II, pp. 474-475; t. IV.

LANDROVE DÍAZ, G., El delito de usura (Barcelona, 1968).

LASSO GAITE, J. F., Crónica de la Codificación española. 5. Codificación penal (Madrid, 1970), v. II, apd. VI [ACGCP], a. 26, ses. 28-V-1845

MARTÍNEZ, M. S., Librería de jueces, utilísima y universal (Madrid, 1791).

MARTORELLI DA OSIMO, L., Dell'usura (Roma, 1809).

MARX, C., El capital: crítica de la economía política, trad. W. Roces (Méjico, 1973), V. III.

MASFERRER DOMINGO, A., La pena de infamia en el Derecho histórico español: contribución al estudio de la tradición penal europea en el marco del ius commune (Madrid, 2001).

MASFERRER DOMINGO, A., Tradición y reformismo en la Codificación penal española: hacia el ocaso de un mito. Materiales, apuntes y reflexiones para un nuevo enfoque metodológico e historiográfico del movimiento penal europeo (Jaén, 2003). 
MASTROFINI, M., Tratado de la usura, trad. M. J. de Ibargüengoitia (Barcelona, 1859).

MONTESQUIEU, Barón de, Del espíritu de las leyes, trad. M. Blázquez y P. de Vega (Madrid, 2003).

PACHECO, J. F., El Código Penal concordado y comentado, ed. A. Téllez Aguilera (Madrid, 2000).

PÉREZ Y LÓPEZ, A. X., Teatro de la legislacion universal de España é Indias (Madrid, 1791/1798).

PROUDHON, P.-J., La pornocracia o la mujer en nuestros tiempos, trad. A. Peratoner (Madrid, 1995).

RAUTER, J. F., Théorique et pratique du Droit criminel français, ou cours de législation criminelle (Paris, 1836).

SAINZ GUERRA, J., La evolución del Derecho Penal en España (Jaén, 2004).

SALA, J., Ilustración del Derecho real de España (Madrid, 1832)

SÁNCHEZ GONZÁLEZ, M. D. M., La codificación penal en España: los códigos de 1848 y 1850 (Madrid, 2004).

TAPIA, E. de, Febrero novísimo, ó Librería de jueces, abogados y escribanos, refundida, ordenada bajo nuevo método, y adicionada con un tratado del juicio criminal, y algunos otros (Valencia, 1828/1831).

TOMÁS Y VALIENTE, F., El Derecho penal de la Monarquía absoluta (siglos XVI, XVII y XVIII) (Madrid, 1969).

TOMÁS Y VALIENTE, F., Manual de Historia del Derecho español (Madrid, 1981).

TURGOT, A.-R. J., Memoria sobre los préstamos de dinero, trad. J. E. (París, 1828).

VALDÉS, R. F., Diccionario de legislacion y jurisprudencia criminal, en que se comprenden todas las disposiciones que rigen en la isla de Cuba, segun las leyes especiales orgánicas de su administracion de Justicia, y autos acordados vijentes (La Habana, 1859).

VALLÉS Y PUJALS, J., Del préstamo a interés, de la usura y de la hipoteca (Barcelona, 1933).

VILANOVA Y MAÑES, S., Materia criminal forense, ó tratado universal teórico y práctico, de los delitos y delincuentes en género y especie, para la segura y conforme expedicion de las causas de esta naturaleza (París, 1827).

VIZCAÍNO PÉREZ, V., Codigo y práctica criminal, arreglado a las leyes de España (Madrid, 1797). 
VIZCARRO, C. F., El préstamo usurario (Barcelona, 1963).

VOLTAIRE, Diccionario filosofico, trad. C. Lanuza (Nueva York, 1825). 